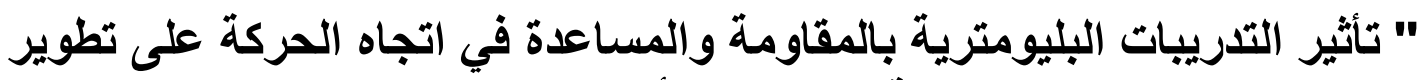

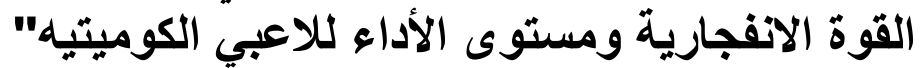

د. محمود ربيع امين البشيهي

- المقدمة ومشكلة البحث:

إن عملية التدريب الرياضي تهدف الى الوصل الي تحقيق البطولات ليس المحلية والقارية

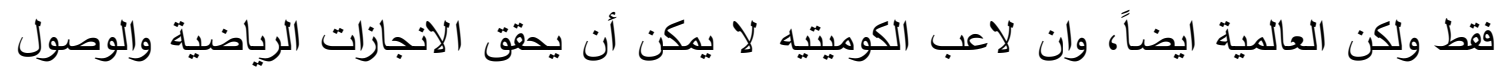

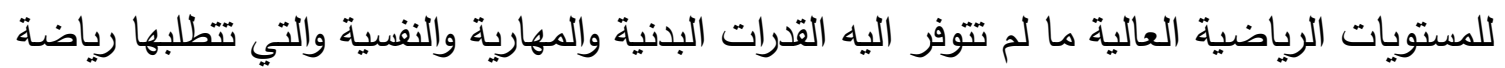

الكاراتيه، وعليه يتم تتمية وتطوير هذه القدرات وذلك من خلال البرامج التدريبية المقننة. حيث يهدف التدريب الرياضي الى اعداد الفرد من خلال تتمية القدرات البدنية والمهارية

والخططية والنفسية لتحقيق أعلي مستوى ممكن في نوع معين من الانشطة الرياضية.(3: 13) ولقد خطى التدريب الرياضي خطوات واسعة في طريق العلم، حيث توسع في استخدام

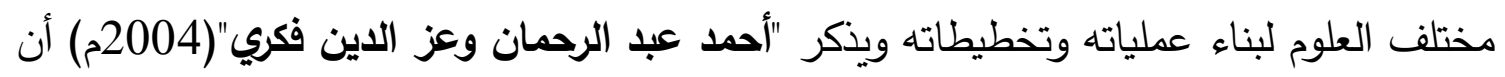

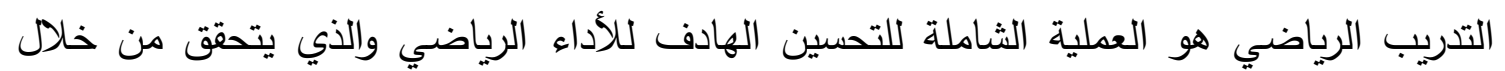
برنامج مخطط للإعداد والمنافسات فهو عملية ممارسة منظمة تتميز بالديناميكية.(4: 30) ويشير "وجيه شمندي" (2002م) إلي أن تخطيط التدريب في رياضة الكاراتيه بأساليب علمية للوصول باللاعب إلي أعلي المستويات يعتبر من أهم الدعائم الرئيسية لنجاح العملية التدريبية.(23: 185)

وفي تدريب رياضة الكاراتيه هناك وسائل عديدة للوصول بالرياضي إلى القوة العضلية منها استخدام تدريبات الأجهزة والأدوات ومن هذه الأجهزة والأدوات المقاعد السويدية والصناديق الخشبية

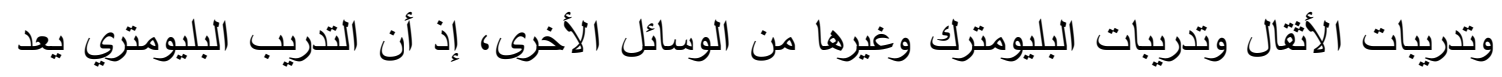

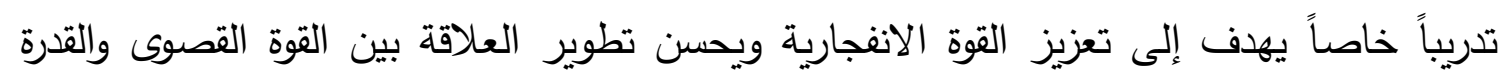
الانفجارية، لذا فقد برز هذا النوع من التدريب بسرعة، فأصبح من أشهر وسائل التدريب لكل التهائل

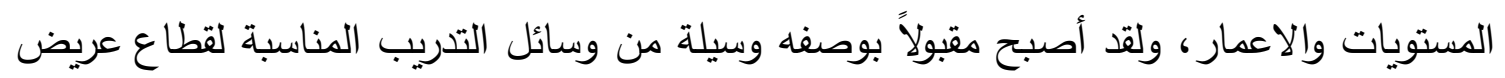
من الأنشطة الرياضية التي تؤدي فيها القوة دوراً كبيراً. $(65: 3)$

والتدريب البليومتري تمرينات تجمع بين القوة والسرعة وتعتمد علي رد فعل، تعمل علي

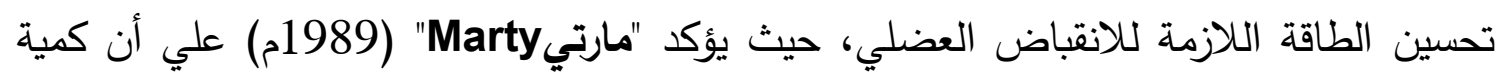

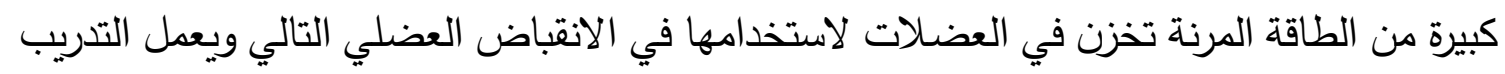


البليومتري علي الاستفادة من هذه الطاقة وتحويلها من طاقة كيميائية إلى طاقة ميكانيكية، وبذلك

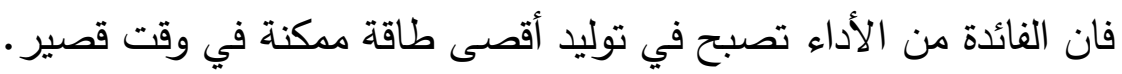

(214:28)

ويذكر "أيهاب عبد الفتاح وجمال فارس"(2001م) إلي أن الغرض الأساسي للتدريب البليومتري هو تحويل الطاقة التي تعتمد علي المرونة التي نحصل عليها من خلال وزن الجسم وقوة

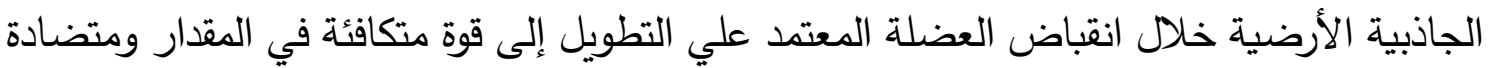

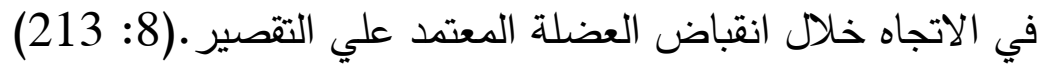
ويؤكد "وليم برانت William Prentice" (1996م) ان تدريبات البليومتريك هي تلكي الكيات التدريبات التي تحتوي على الوثبات، والقفزات، والرمي والدفعات التي صدمت لجعلك اسرع، وفي التدريبات البليومترية يجب ان يكون الاداء سريع، ولو تم التدريب ببطء فإن العضلات سوف تتعود

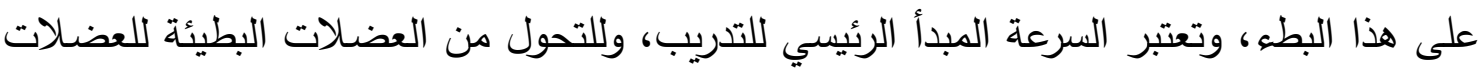
السريعة يتطلب ذلك حركات سريعة (متفجرة) وهذه النشاطات تتم من خلال تقليل زمن الاتصال

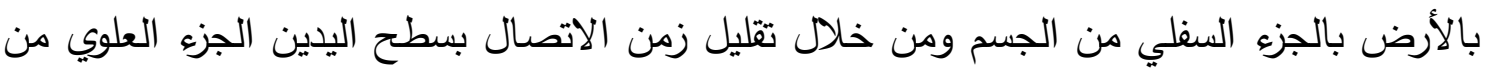

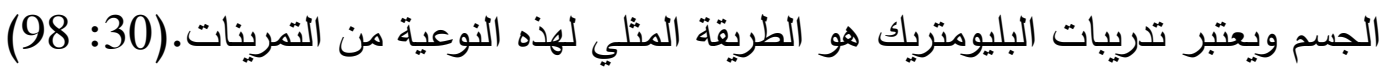
ورياضة الكاراتيه هي رياضة قتالية نبيلة الممارسة، عريقة النشأة، يابانية الميلاد، منتشرة

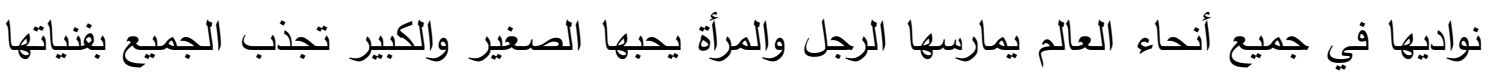

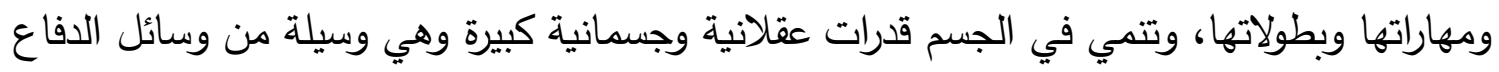
بدون سلاح.(6: (6) - (6)

ويسعى الاتحاد الدولي للكاراتيه إلى تطوير المستوى الفني لرياضة الكاراتيه عامة والكوميتيه

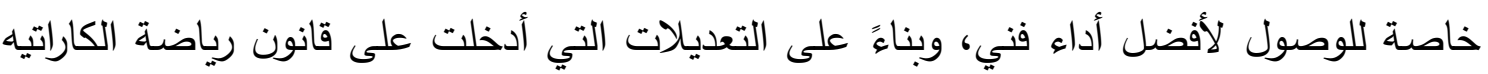

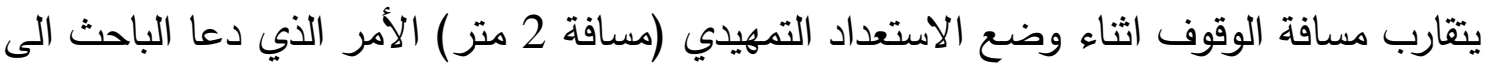

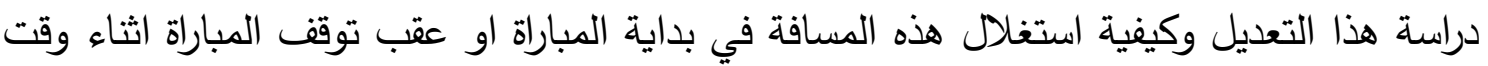

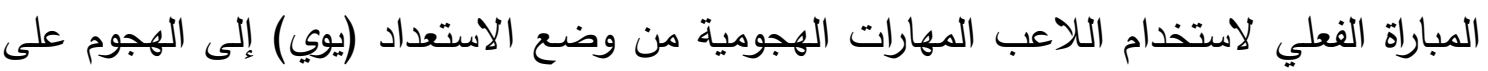

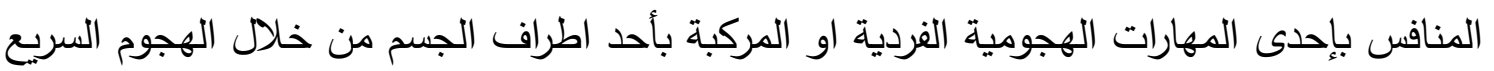

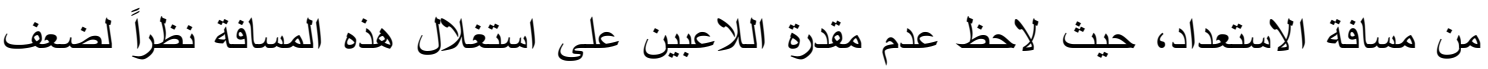
عضلات الرجلين (السمانة - الامامية - الخلفية) في الانطلاق للهجوم وعدم استخدام التدريبات التاني البليومترية مما وجه نظر الباحث الى استخدام تدريبات بليومترية بالمقاومات في اتجاه الحركة واتجاه

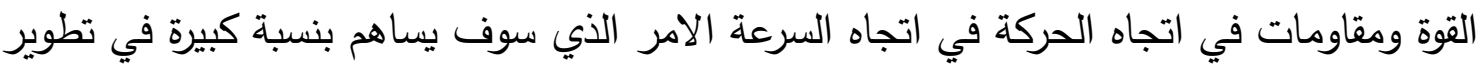
القوة الانفجارية الذي سوف يساعد على الانطلاق للهجوم بأحد اطراف الجسم ومن ثم اداء المهارات الهجومية الفردية والمركبة لتسجيل النقاط واحراز الفوز في المباريات. 


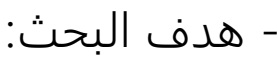

تهدف الدراسة الى استخدام التدريبات البليومترية بالمقاومة والمساعدة في اتجاه الحركة على تطوير القوة الانفجارية ومستوى الأداء للاعبي الكوميتيه.

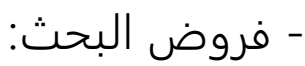
1- توجد فروق دالة احصائية بين القياسين القبلي والبعدي لأفراد عينة البحث في القدرات البدنية الخاصة بالقدرة العضلية لصالح القياس البعدي. r- توجد فروق دالة احصائية بين القياسين القبلي والبعدي لأفراد عينة البحث في القدرات البدنية

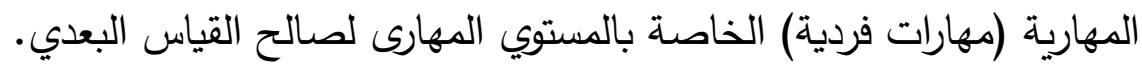

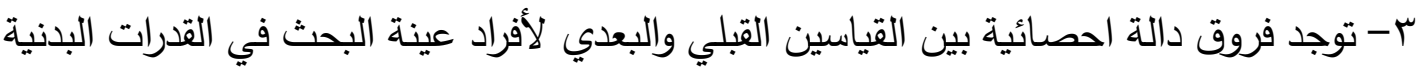
المهارية (مهارات مركبة) الخاصة بالمستوي المهارى لصالح القياس البعدي. ؟-توجد نسبة تحسن في القدرات البدنية الخاصة بالقدرة العضلية والقدرات البدنية المهارية(مهارات فردية) والقدرات البدنية المهارية (مهارات مركبة) الخاصة بالمستوي المهارى لأفراد عينة البحث (بين القياسين القبلي والبعدي) لصالح القياس البعدي.

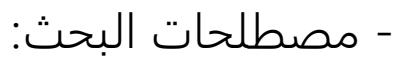
التتريبات البليومترية بالمقاومة والمساعدات "هي مجموعة من التدريبات التي تعتمد على الانقباض بالتقصير باستخدام مقاومات في باتئي

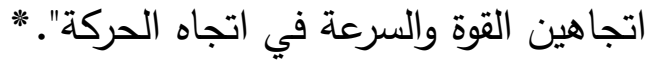

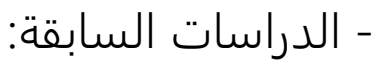
- أجري "اونس وآخرون Ionic et all - (2000م) دراسة بعنوان " تأثير تدريبات البليومتريك والأثقال على مسافة الوثب العمودي وقوة الرجلين"، وتهدف هذه الدراسة الى التعرف على تأثير تدريبات

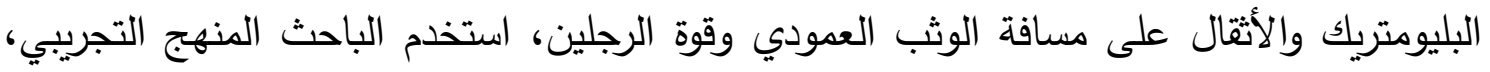

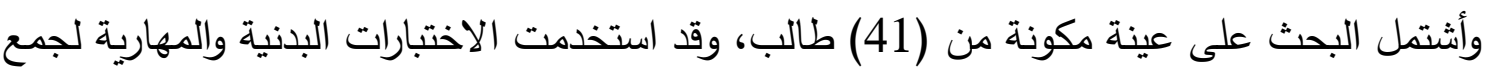

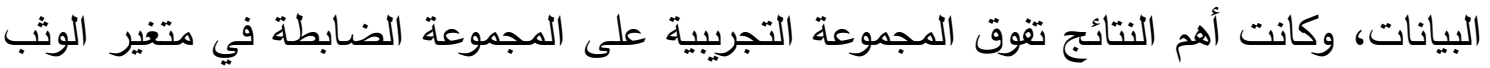
العمودي وقوة الرجلين.(27) - أجري " ترنييه وآخرون Trnier AM, \& et al" (2003م) دراسة بعنوان "تحسين في (2013 اقتصاديات الجري بعد ستة اسابيع من التدريب البليومتريك"، وتهاف هذه الدراسة الى معرفة تحسين

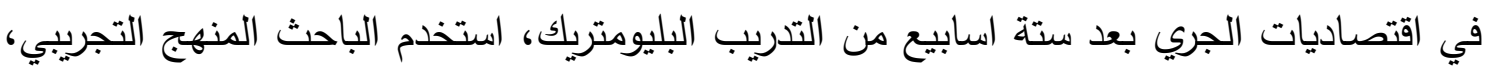

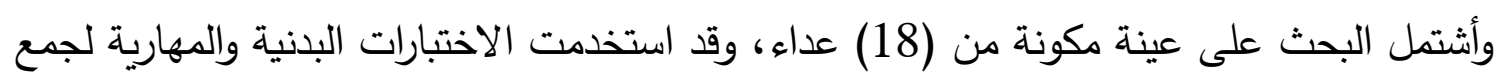


البيانات، وكانت أهم النتائج التدريب البليومتريك لمدة 6 اسابيع يحسن الجري المنتظم ولكن ليس لعدائين المسافات الطويلة.(24) - Stantos \& Janeira أجري "ستانيتوس وجانيرا (2011م) دراسة بعنوان "آثار تدريب المقاومة

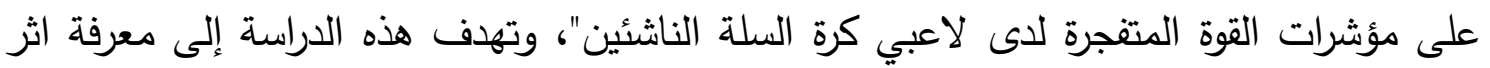

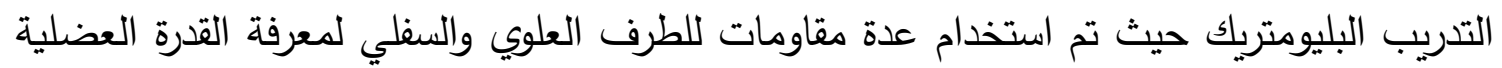
لاى لاعبي كرة السلة الناشئين، استخدم الباحث المنهج التجريبي، وأثتمل البحث على على عينة مكونة

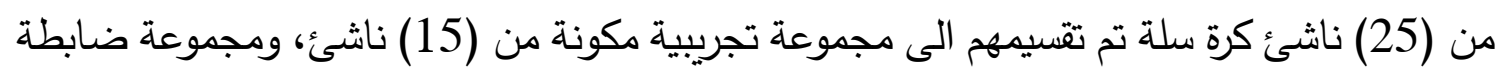

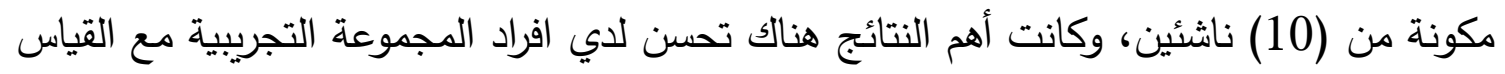

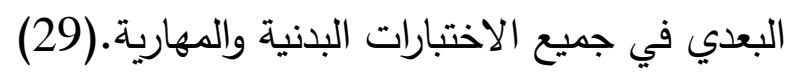
- أجري "بختيار صادق سليم" (2015م) دراسة بعنوان " تأثير برنامج تدريبي بإستخدام تدريبات

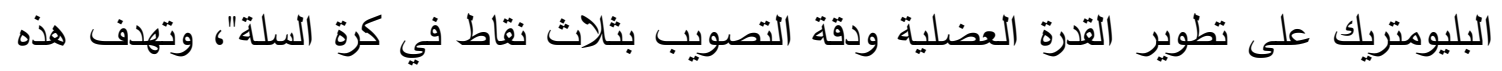

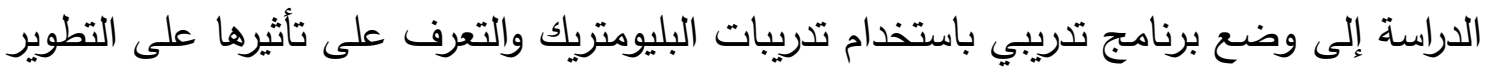

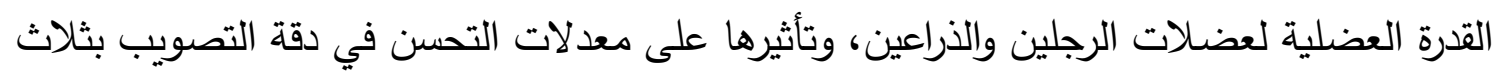

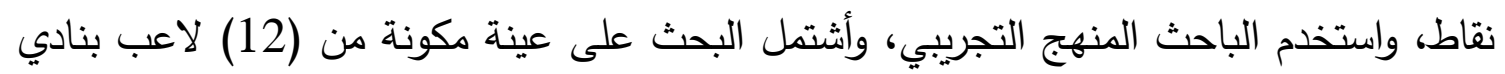

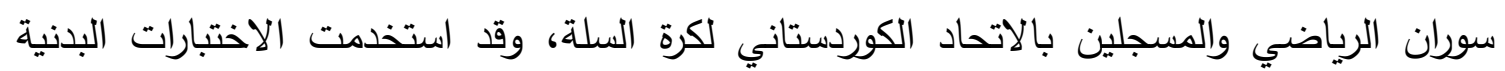

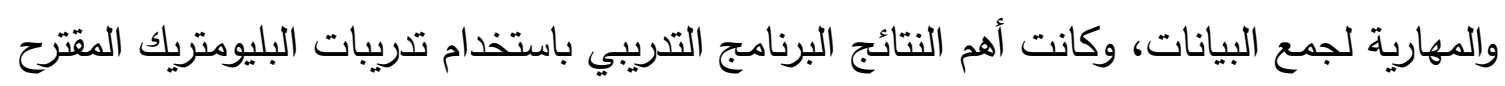
يؤثر إيجابياً وبدلالة معنوية على تطوير القدرة العضلية لكل من الرجلين والذراعين لناشئ كرة السلة

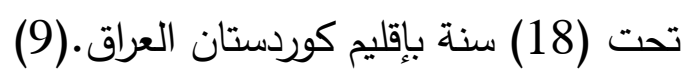

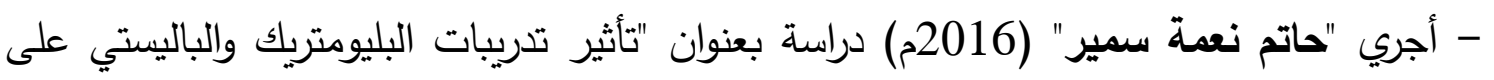

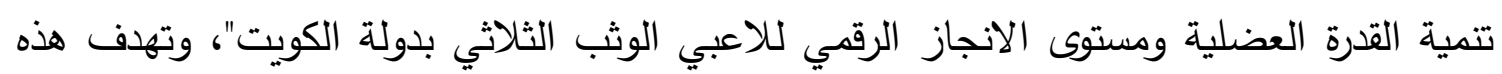

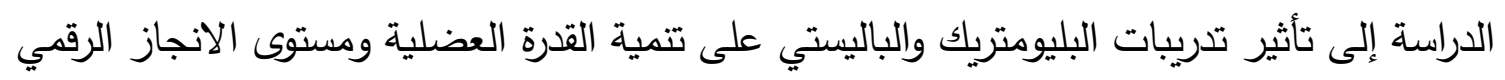

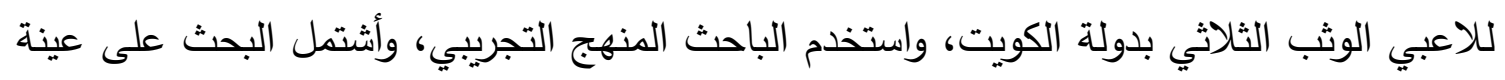

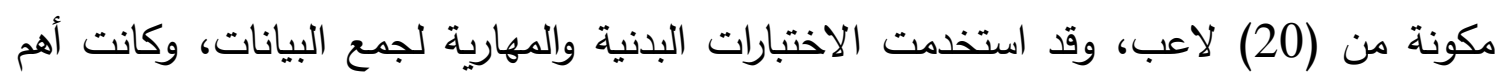
النتائج حقق البرنامج التدريبي المقترح باستخدام اسلوب التدريب البالستي الاهداف المتوقعة (البدنية

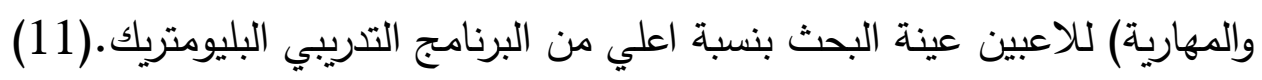

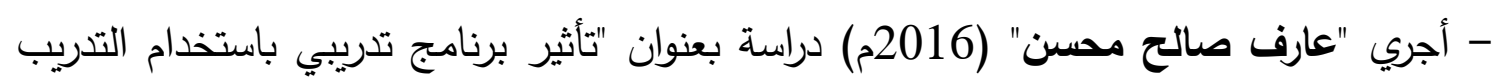

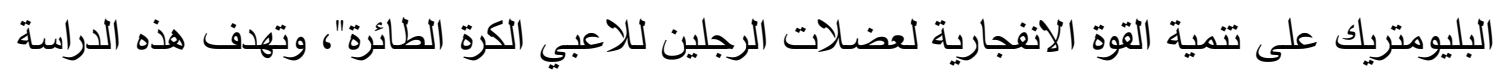

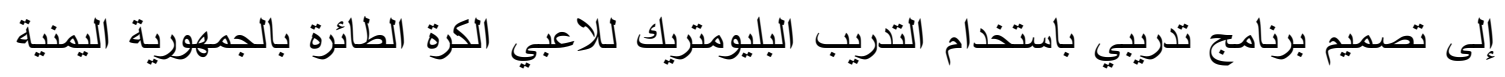

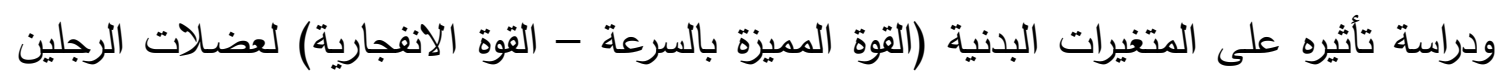

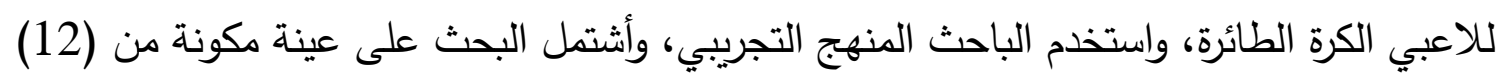


لاعب، وقد استخدمت الاختبارات البدنية والمهارية لجمع البيانات، وكانت أهم النتائج وجود فروق

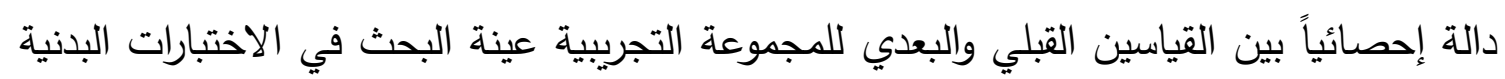

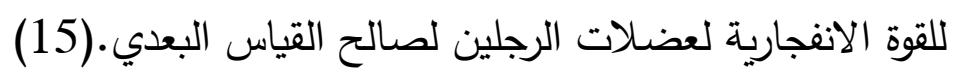

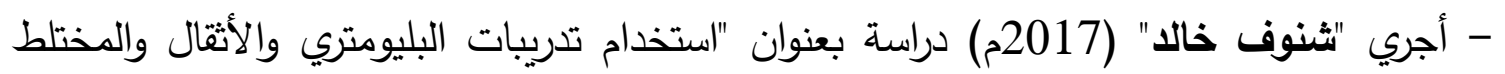
لتطوير القوة الانفجارية وتأثيرها على بعض القدرات البدنية لدى مصارعي الكاراتيه"، وتهدف هذه دانه

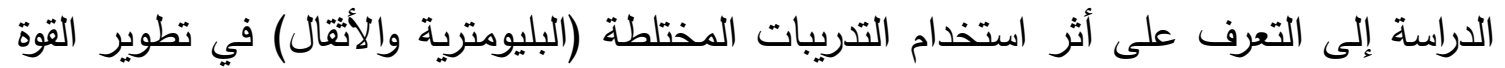

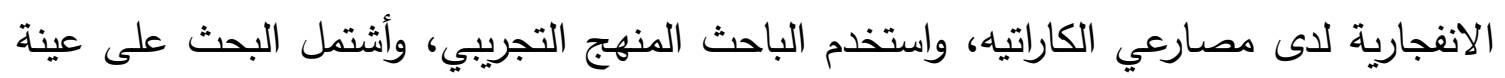

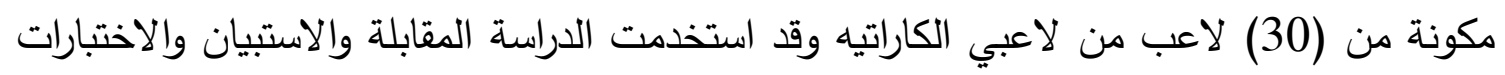
البدنية لجمع البيانات، وكانت أهم النتائج توجد فروق دالة الكاريه وفي إحصائيا بين الأساليب التدريبية المستعملة

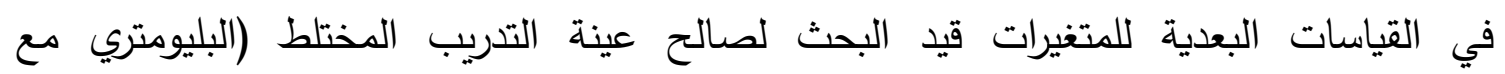
(14). (14) (الأثقال)

- الاستفادة من الدراسات السابقة: ساعدت الدراسات السابقة الباحث في اختيار منهجية البحث وتحديد أهداف البرنامج التدريبي وكذلك تصميم البرنامج التدريبي، بالإضافة الى اختيار أدوات جمع البيانات سواء بدنية، مهارية،

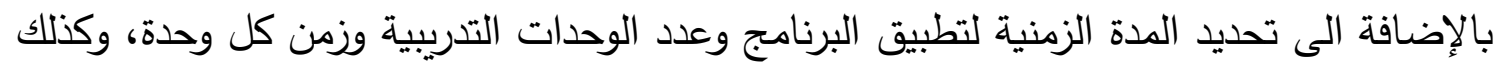

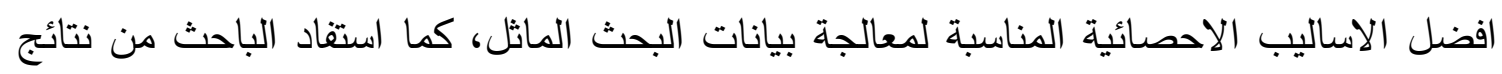
هذه الدراسات في تفسير ومناقثة نتائج البحث الماثل. - إجراءات البحث: 1- منهج البحث: استخدم الباحث المنهج التجريبي لمناسبته لطبيعة الدراسة واجراءاته، وذلك من خلال التصميم التجريبي لمجموعة واحدة تجريبية عن طريق القياسين (القبلي والبعدي). 2- مجتمع وعينة البحث: يمثل مجتمع البحث لاعبي منتخب مصر القومي الأول (رجال) فوق 18 سنة والحاصلين على الحزام الأسود (1) دان كحد ادنى والمسجلين بسجلات الاتحاد المصري للكاراتيه والبالغ عددهم (20) لاعب متمثلين في خمس اوزان ( 60 - 67 - 75 - 84)، حيث تم اختيار عينة البحث بالطريقة العمدية حيث بلغ حجم العينة (20) لاعب حيث تم اختيار عدد (10) (10) لاعب للادراسة الاستطلاعية وعدد (10) للدراسة الأساسية متمثلين بعدد (5) موازيين بواقع (2) لاعب في كل ميزان لاعند

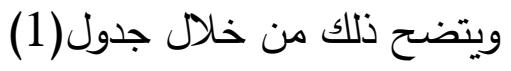


جدول(1)

توصيف عينة البحث

\begin{tabular}{|c|c|c|c|}
\hline النسبة المئوية & العدد & نوع العينة & م \\
\hline$\% 50$ & 10 & العينة الاستطلاعية & 1 \\
\hline$\% 50$ & 10 & العينة الأساسية & 2 \\
\hline$\% 100$ & 20 & المجموع & \\
\hline
\end{tabular}

اعتدالية توزيع عينة البحث:

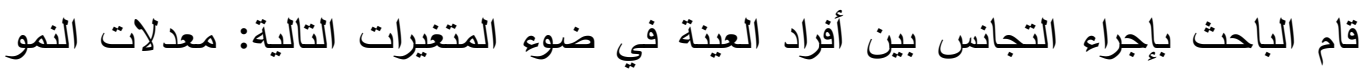

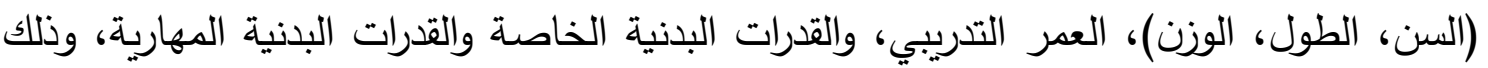

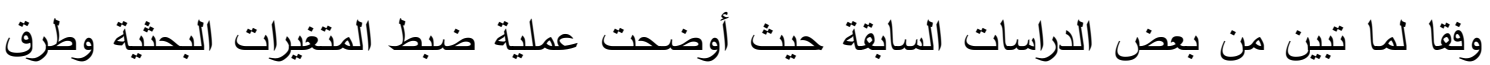
تجانس أفراد العينة وجدول (2) يوضح التجانس بين أفراد العينة.

جدول (2)

اعتدالية توزيع عينة الدراسة في متغيرات النمو (السن -

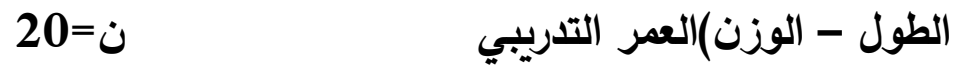

\begin{tabular}{|c|c|c|c|c|c|c|}
\hline معامل & الوسيط & الانحراف المعياري & المتوسط الحسابي & القياس & البيان & r \\
\hline $0.27-$ & 23.00 & 1.69 & 22.85 & سنة & السن & 1 \\
\hline 0.31 & 174.00 & 6.68 & 174.70 & سم & الطول & 2 \\
\hline 0.02 & 73.00 & 10.31 & 73.05 & كجم & الوزن & 3 \\
\hline $0.18^{-}$ & 17.00 & 1.68 & 16.90 & سنة & العمر التدريبي & 4 \\
\hline
\end{tabular}

يوضح جدول (2) المتوسط الحسابي والانحراف المعياري وقيمة معامل الالتواء لعينة البحث في جميع المتغيرات (النمو - العمر التدريبي) حيث يتضح أن قيم معاملات الالتواء تراوحت ما بين

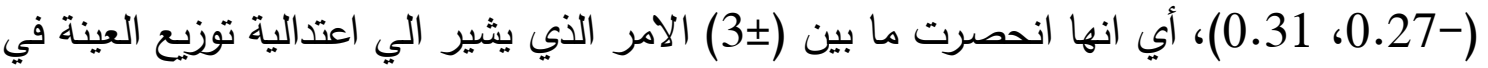


جدول (3)

اعتدالية توزيع عينة الدراسة في القدرات البنية الخاصة

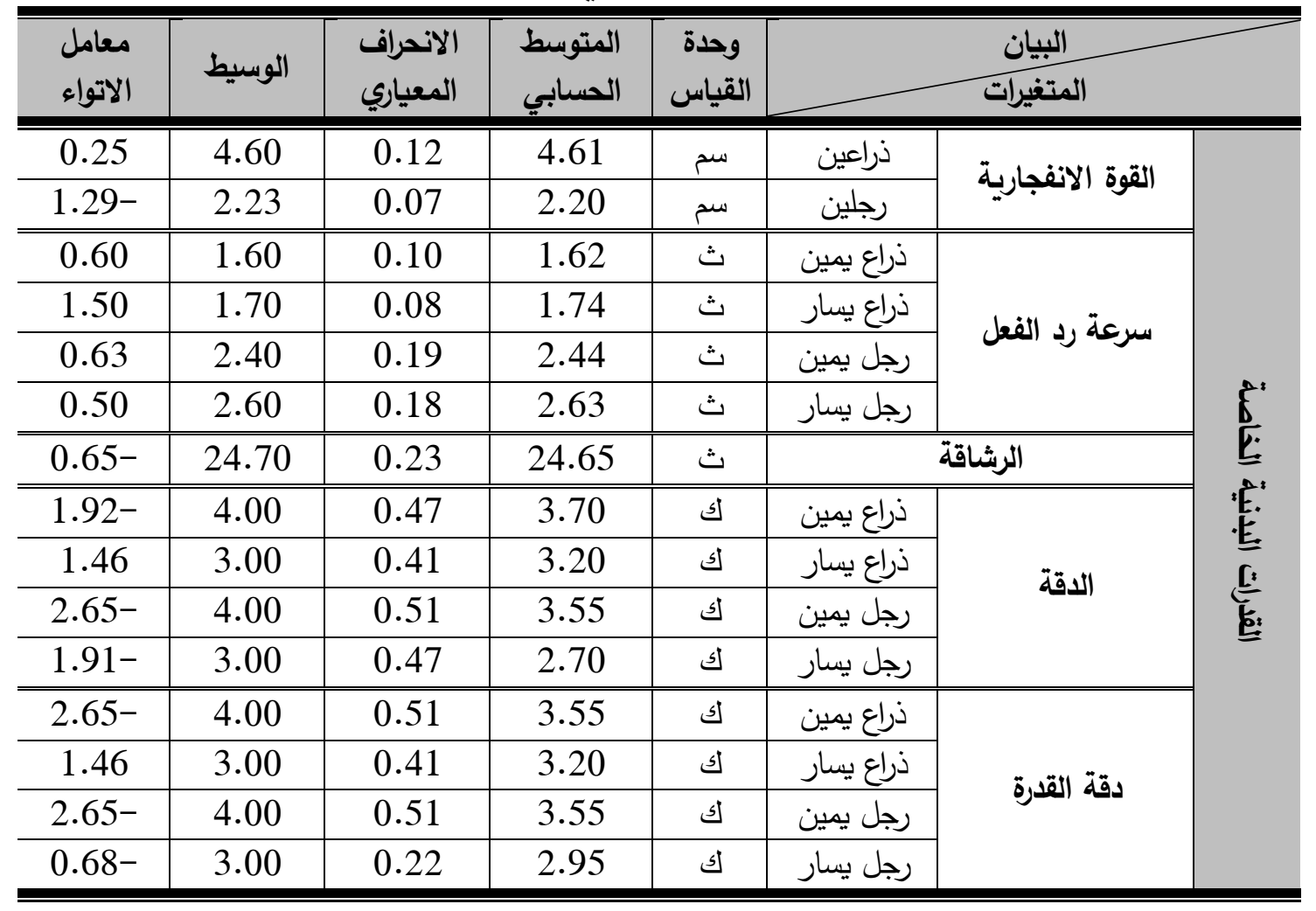

يوضح جدول (3) المتوسط الحسابي والانحراف المعياري وقيمة معامل الالتواء لعينة البحث

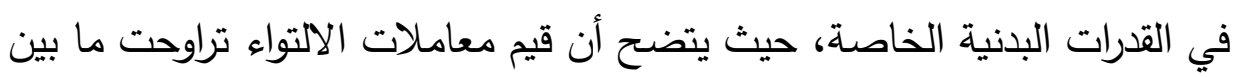

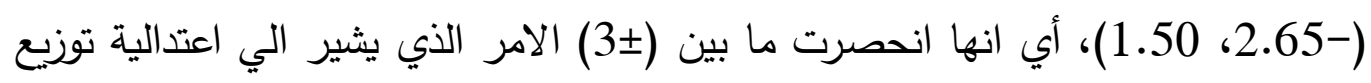


جدول (4)

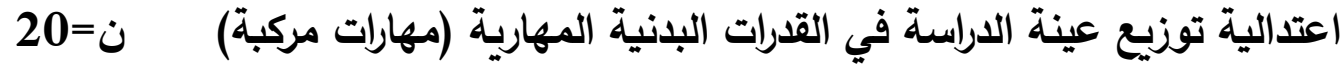

\begin{tabular}{|c|c|c|c|c|c|c|c|}
\hline ماتلواء & الوسيط & المعياري & الحسابي & القياس & \multirow{5}{*}{\multicolumn{2}{|c|}{ المالسرعة }} & \\
\hline $0.35-$ & 17.00 & 0.85 & 16.90 & ث & & \multirow{4}{*}{ بالمريزة } & \\
\hline 0.78 & 18.00 & 0.77 & 17.80 & ث & & & \\
\hline 2.65 & 7.00 & 0.51 & 7.45 & $\dot{H}$ & & & \\
\hline 1.46 & 7.00 & 0.41 & 7.20 & ث & & & \\
\hline $0.75^{-}$ & 28.50 & 1.20 & 28.20 & ث & كيزامي جياكو جودان & \multirow{4}{*}{ تحمل القدرة } & \\
\hline 1.58 & 31.00 & 0.95 & 31.50 & ث & كيزامي كواكي مواشي & & \\
\hline 2.65 & 15.00 & 0.51 & 15.45 & $\dot{\Delta}$ & جياكو اورا مواشي & & \\
\hline $042^{-}$ & 16.00 & 0.72 & 15.90 & ث & كيزامي اورا مواشي & & \\
\hline 0.97 & 5.00 & 0.31 & 5.10 & ث & كيزامي جياكو جودان & \multirow{4}{*}{ دقة القدرة } & \\
\hline 1.46 & 5.00 & 0.41 & 5.20 & ث & كيزامي كواكي مواشي & & \\
\hline $2.65^{-}$ & 6.00 & 0.51 & 5.55 & $\dot{\Delta}$ & جياكو اورا مواشي & & \\
\hline 2.40 & 5.00 & 0.50 & 5.40 & ث & كيزامي اورا مواشي & & \\
\hline
\end{tabular}

يوضح جدول (4) المتوسط الحسابي والانحراف المعياري وقيمة معامل الالتواء لعينة البحث

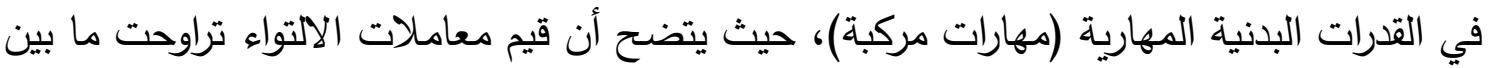

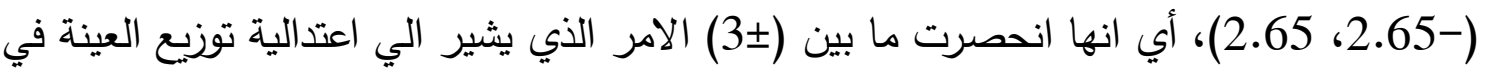
جميع هذه القدرات.

جدول (5)

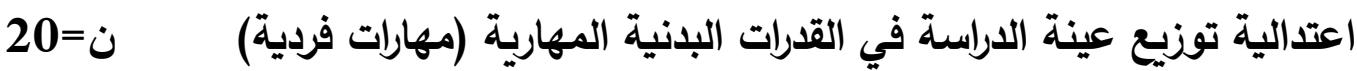

\begin{tabular}{|c|c|c|c|c|c|c|c|}
\hline الاتواء & الوسيط & الالاحراف & الحسابي & القياس & & & \\
\hline 0.42 & 9.00 & 0.72 & 9.10 & ث & كيزامي جياكو جودان & \multirow{4}{*}{ المبزة } & \multirow{10}{*}{ 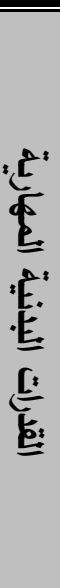 } \\
\hline 0.22 & 9.00 & 0.69 & 9.05 & $\dot{H}$ & كيزامي كواكي مواشي & & \\
\hline $2.65^{-}$ & 6.00 & 0.51 & 5.55 & ث & جياكو اورا مواشي & & \\
\hline $2.65^{-}$ & 6.00 & 0.51 & 5.55 & $ث$ & كيزامي اورا مواشي & & \\
\hline 0.78 & 14.00 & 0.77 & 14.20 & ث & كيزامي جياكو جودان & \multirow{4}{*}{ تحدمل } & \\
\hline $0.97-$ & 13.00 & 0.62 & 12.80 & ث & كيزامي كواكي مواشي & & \\
\hline $0.42-$ & 14.00 & 0.72 & 13.90 & ث & جياكو اورا مواشي & & \\
\hline 0.35 & 14.00 & 0.85 & 14.10 & ث & كيزامي اورا مواشي & & \\
\hline 0.97 & 5.00 & 0.31 & 5.10 & ث & كيزامي جياكو جودان & \multirow{2}{*}{ دقة القدرة } & \\
\hline $2.40^{-}$ & 6.00 & 0.50 & 5.60 & ث & كيزامي كواكي مواشي & & \\
\hline
\end{tabular}




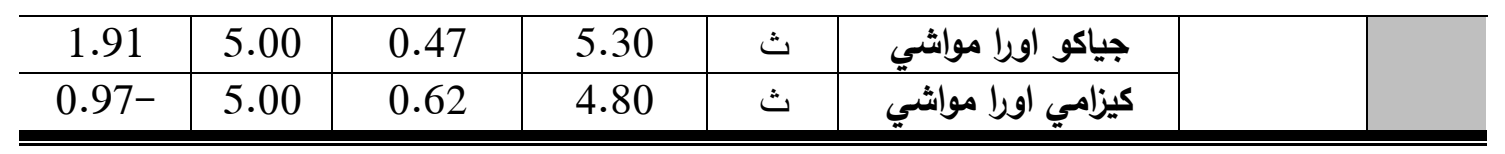

يوضح جدول (5) المتوسط الحسابي والانحراف المعياري وقيمة معامل الالتواء لعينة البحث

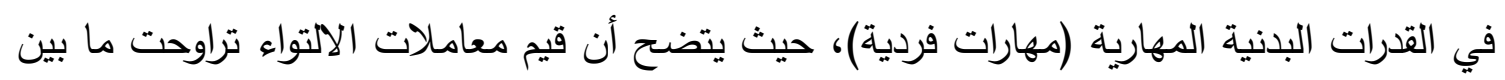

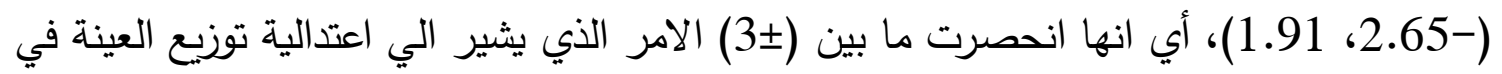
جميع هذه القدرات. - وسائل وادوات جمع البيانات: قام الباحث بتحديد أدوات ووسائل جمع البيانات الخاصة بالدراسة من خلال الاطلاع على الى الئل المراجع العلمية المتخصصة، وكذلك الدراسات المرتبطة بموضوع الدراسة والتي تتضح من خلاد لئل

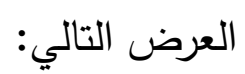

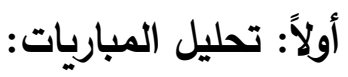

قام الباحث بتحليل بعض مباريات بطولة الجمهورية موسم ( 2018 ) التي أقيمت بإستاد القاهرة الدولي صالة ( 3 ) والتي حصل فيها اللاعبون عينة الدراسة على الأربع مراكز الأولى وذلك الكئل

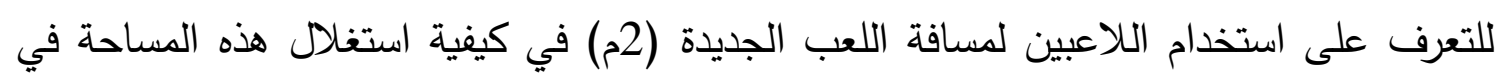

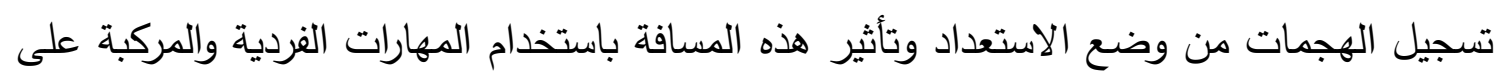
تطوير مستوى الأداء وقد اشتمل التحليل على المحاور الآتية: المحور الأول: تحديد وقفة استعداد اللاعب (أيمن - أيسر). المحور الثاني: تحديد المهارات الهجومية التي نفذها اللاعبون من خلال مسافة اللعب (2م) التهن). المحور الثالث: تحديد فاعلية تتفيذ هذه المهارات في احراز النقاط. ثانياً: قياس بعض القدرات البذنية الخاصة:

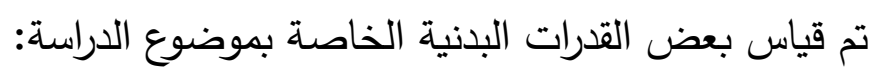

$$
\text { - - - القوة الانفجارية (الذراعين - الرجلين). }
$$

كما تم قياس بعض القدرات البدنية المهارية المرتبطة بموضوع الدراسة لبعض المهارات الفردية: - القوة المميزة بالسرعة للذراعين والرجلين (فردي - مركب). - تحمل القدرة للذراعين والرجلين (فردي - مركب). - - دقة القدرة للذراعين والرجلين (فردي - مركب). 


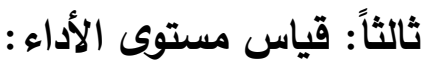
تم قياس مستوى الأداء المهاري من خلال اشتراك اللاعبين في عدد من (3 - 5) مباريات

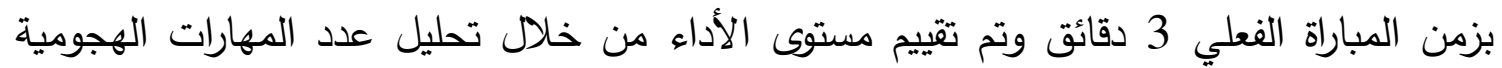
الناجحة والفاشلة لكل لاعب وذلك من خلال استمارة تحليل المباريات. رابعاً: الأجهزة والأدوات المستخدمة: قام الباحث باستخدام الأجهزة والأدوات التالية: - جهاز ريستاميتر لقياس الطول بالسنتيمتر . - وسائد لكم + ركل Sand-Bag

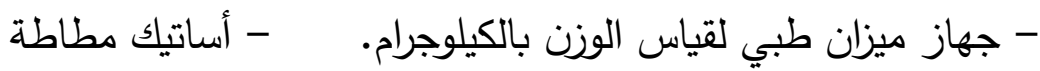

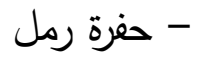
- كاميرا فيديو Video -

- جاكيت اثقال بأوزان مختلفة تتناسب مع وزن

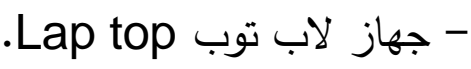
كل لاعب على حده

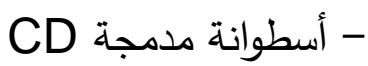
- ساعة ايقاف Stop Watch لقياس الزمن - اثقال ذراعين ورجلين بأوزان مختلفة تتناسب مع لأبه

$$
\text { وزن كل لاعب على حده. - ملن. }
$$

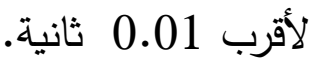

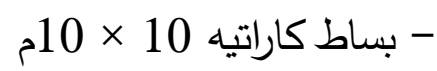
- الدراسة الاستطلاعية: قام الباحث بإجراء الدراسة الاستطلاعية خلال الفترة من يوم الخميس الموافق3 / 3 / / 2019م وحتى يوم الجمعه الموافق 4 / 1 1 19 / 20 م على عينة قوامها (10) لاعبين من المجتمع الأصلي للدراسة وخارج عينة الدراسة الأساسية وذلك بهدف التعرف على: - - تجهيز الأدوات والأجهزة المستخدمة اثناء القياس. - تحديد الصعوبات التي تواجه الباحث عند تتفيذ القياسات. - - تحديد الامن اللازم لإجراء القياسات. - - تدريب المساعدين على كيفية اجراء القياسات.

$$
\text { المعاملات العلمية (الصدق - الثبات) قيد الدراسة: }
$$

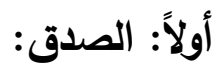

قام الباحث بحساب معامل صدق التمايز للقياسات قيد البحث من خلال تطبيق القياسات

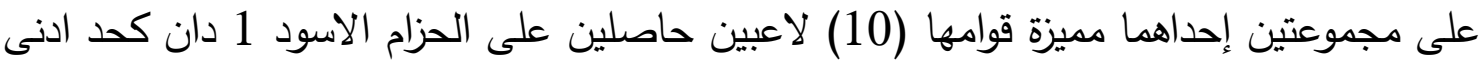

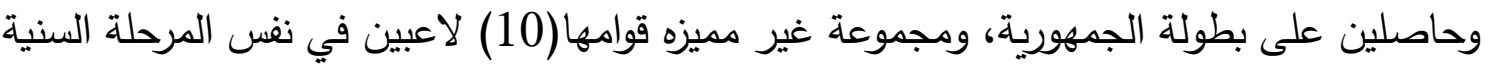
وهم أفراد مجموعة البحث الأستطلاعية، وقد تم حساب قيمة "ت" بين المجموعتين المميزة وغير 
المميزة في اختبارات القدرات البدنية الخاصة والقدرات البدنية المهارية(دهارات مركبة) والقدرات البدنية المهارية(مهارات فردية) الفترة من 2019/1/9م الى 2019/1/10م، ويتضح ذلك من خلارل الجدولين

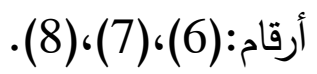

جدول (6)

دلالة الفروق بين المجموعتين المميزة وغير المميزة في

اختبارات القدرات البذنية الخاصة

\begin{tabular}{|c|c|c|c|c|c|c|c|}
\hline \multirow{2}{*}{ قاتمة } & \multicolumn{2}{|c|}{ المجموعة غير المميزة } & \multicolumn{2}{|c|}{ المجموعة المميزة } & \multirow{2}{*}{ القياس } & \multirow[t]{2}{*}{ البيان } & \multirow[b]{2}{*}{ المتغيرات } \\
\hline & $\varepsilon^{ \pm}$ & 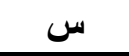 & $\varepsilon^{ \pm}$ & س - مس - مس & & & \\
\hline "*11.48 & 0.08 & 4.13 & 0.10 & 4.62 & سم & ذراعين & \multirow{2}{*}{ القوة الانفجارية } \\
\hline$* 6.31$ & 0.09 & 1.96 & 0.07 & 2.20 & سم & رجلين & \\
\hline$* 4.69$ & 0.08 & 1.82 & 0.10 & 1.62 & ث & ذراع يمين & \multirow{4}{*}{ سرعة رد الفعل } \\
\hline$* 5.40$ & 0.06 & 1.92 & 0.08 & 1.74 & ث & ذذراع يسار & \\
\hline$* 5.43$ & 0.08 & 2.83 & 0.20 & 2.44 & ث & رجل يمين & \\
\hline$* 3.13$ & 0.13 & 2.87 & 0.19 & 2.63 & $\dot{H}$ & رجل يسار & \\
\hline *4.00 & 0.11 & 24.99 & 0.23 & 24.65 & ث & & الر الرشاقة \\
\hline $2 * 3.12$ & 0.32 & 3.10 & 0.48 & 3.70 & 5 & ذذراع يمين & \multirow{4}{*}{ الاقة } \\
\hline$* 2.56$ & 0.21 & 2.80 & 0.42 & 3.20 & ك & ذذراع يسار & \\
\hline$* 3.44$ & 0.32 & 2.90 & 0.52 & 3.60 & ك5 & رجل يمين & \\
\hline$* 3.12$ & 0.32 & 2.10 & 0.48 & 2.70 & 5 & رجل يسار & \\
\hline$* 3.57$ & 0.09 & 3.10 & 0.41 & 3.60 & 5 & ذراع يمين & \multirow{4}{*}{ دقة القرة } \\
\hline$* 2.66$ & 0.11 & 2.90 & 0.32 & 3.20 & ك & ذذراع يسار & \\
\hline$* 4.51$ & 0.15 & 3.20 & 0.22 & 3.60 & ك & رجل يمين & \\
\hline$* 4.16$ & 0.08 & 2.90 & 0.12 & 3.10 & ك & رجل يسار & \\
\hline
\end{tabular}

يتضح من جدول (6) وجود فروق دالة احصائيا عند مستوي معنوية 0.05 بين المجموعة

المميزة والمجموعة الغير مميزة في اختبارات القدرات البدنية الخاصة، ولصالح المجموعة المميزة مما يعطي دلالة مباشرة على صدق الاختبارات. 
جدول (7)

دلالة الفروق بين المجموعتين المميزة وغير المميزة في

اختبارات القدرات البلنية المهارية(مهارات مركبة) ن 10 = ن 10 =

\begin{tabular}{|c|c|c|c|c|c|c|c|}
\hline \multirow{2}{*}{ قيمة } & \multicolumn{2}{|c|}{ المجموعة غير المميزة } & \multicolumn{2}{|c|}{ المجموعة المميزة } & \multirow{2}{*}{ القياس } & \multirow[t]{2}{*}{ البيان } & \multirow[b]{2}{*}{ المتغيرات } \\
\hline & $\varepsilon^{ \pm}$ & س & $\varepsilon^{ \pm}$ & س - l - l & & & \\
\hline 2.45 & 0.10 & 17.30 & 0.48 & 16.90 & ث & كيزامي جياكو جودان & \multirow{4}{*}{ القالسرعة الميزة } \\
\hline$* 2.87$ & 0.15 & 18.20 & 0.39 & 17.80 & $\dot{H}$ & كيزامي كواكي مواشي & \\
\hline$* 2.71$ & 0.19 & 7.90 & 0.52 & 7.40 & ث & جياكو اورا مواشي & \\
\hline$* 2.24$ & 0.21 & 7.55 & 0.42 & 7.20 & 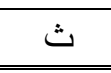 & كيزامي اورا مواشي & \\
\hline$* 2.40$ & 0.30 & 28.75 & 0.62 & 28.20 & $\bar{ث}$ & كيزامي جياكو جودان & \multirow{4}{*}{ تحمل القدرة } \\
\hline$* 2.31$ & 0.22 & 31.90 & 0.47 & 31.50 & $\dot{H}$ & كيزامي كواكي مواشي & \\
\hline$* 2.44$ & 0.19 & 15.85 & 0.52 & 15.40 & $\dot{H}$ & جياكو اورا مواشي & \\
\hline$* 2.66$ & 0.20 & 16.25 & 0.34 & 15.90 & $\dot{H}$ & كيزامي اورا مواشي & \\
\hline$* 2.17$ & 0.13 & 5.35 & 0.32 & 5.10 & 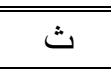 & كيزامي جياكو جودان & \multirow{4}{*}{ دقة القدرة } \\
\hline$* 2.46$ & 0.08 & 5.55 & 0.42 & 5.20 & $\dot{H}$ & كيزامي كواكي مواشي & \\
\hline$* 3.38$ & 0.15 & 5.90 & 0.22 & 5.60 & $\dot{H}$ & جياكو اورا مواشي & \\
\hline$* 2.14$ & 0.21 & 5.80 & 0.52 & 5.40 & ث & كيزامي اورا مواشي & \\
\hline
\end{tabular}

* قيمة (ت) الجدولية عند مستوي 2.1010 .05

يتضح من جدول (7) وجود فروق دالة احصائيا عند مستوي معنوية 0.05 بين المجموعة

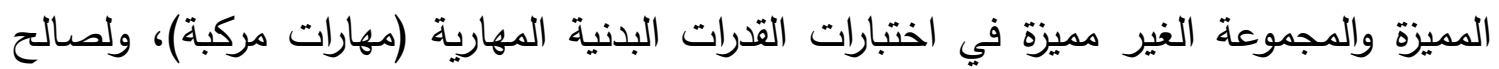
المجموعة المميزة مما يعطي دلالة مباشرة على صدق الاختبارات. 
جدول (8)

دلالة الفروق بين المجموعتين المميزة وغير المميزة في

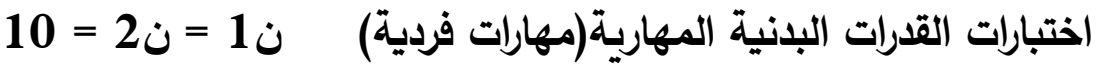

\begin{tabular}{|c|c|c|c|c|c|c|c|}
\hline \multirow{2}{*}{ قيمة } & \multicolumn{2}{|c|}{ المجموعة غير المميزة } & \multicolumn{2}{|c|}{ المجموعة المميزة } & \multirow{2}{*}{ القياس } & \multicolumn{2}{|l|}{ البيان } \\
\hline & $\varepsilon^{ \pm}$ & س - ف - ن & $\varepsilon^{ \pm}$ & 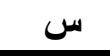 & & & 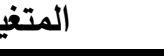 \\
\hline$* 2.11$ & 0.29 & 9.45 & 0.57 & 9.00 & ث & كيزامي جياكو جودان & \\
\hline$* 2.39$ & 0.24 & 9.50 & 0.44 & 9.10 & ث & كيزامي كواكي مواشي & \\
\hline$* 2.90$ & 0.17 & 5.95 & 0.32 & 5.60 & ث & جياكو اورا مواشي & \\
\hline$* 2.34$ & 0.18 & 6.10 & 0.48 & 5.70 & ث & كيزامي اورا مواشي & \\
\hline$* 2.23$ & 0.32 & 14.70 & 0.59 & 14.20 & ث & كيزامي جياكو جودان & \\
\hline$* 2.54$ & 0.25 & 13.15 & 0.33 & 12.80 & ث & كيزامي كواكي مواشي & ت \\
\hline$* 2.16$ & 0.27 & 14.40 & 0.64 & 13.90 & ث & جياكو اورا مواشي & تحمل العره \\
\hline *2.13 & 0.18 & 14.60 & 0.68 & 14.10 & $\dot{H}$ & كيزامي اورا مواشي & \\
\hline$* 3.75$ & 0.24 & 5.60 & 0.32 & 5.10 & ث & كيزامي جياكو جودان & \\
\hline$* 2.24$ & 0.21 & 5.95 & 0.42 & 5.60 & ث & كيزامي كواكي مواشي & \\
\hline$\div 2.12$ & 0.30 & 5.70 & 0.48 & 5.30 & ث & جياكو اورا مواشي & 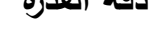 \\
\hline$* 2.78$ & 0.10 & 5.12 & 0.33 & 4.80 & ث & كيزامي اورا مواششي & \\
\hline
\end{tabular}

* قيمة (ت) الجدولية عند مستوي 2.1010 .05

يتضح من جدول (8) وجود فروق دالة احصائيا عند مستوي معنوية 0.05 بين المجموعة

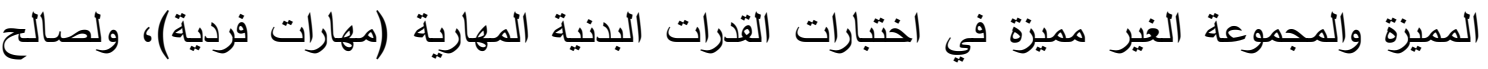

المجموعة المميزة مما يعطي دلالة مباشرة على صدق الاختبارات.

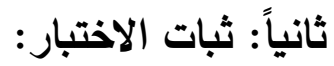

تم حساب معامل الثبات للاختبارات اختبارات القدرات البدنية الخاصة والقدرات البدنية

المهارية(مهارات مركبة) والقدرات البدنية المهارية(مهارات فردية)، عن طريق تطبيق الاختبار واعادة التطبيق Test - Retest على افراد العينة الاستطلاعية وعددهن (10) لاعبين، وبفارق زمني قدره (7) أيام في الفترة من 2019/1/15م الى 2019/1/22م، وجداول (9)،(10)،(11) يوضحا للكئك. 
جدول (9)

معامل الثبات للاختبارات في اختبارات القدرات البدنية الخاصة

\begin{tabular}{|c|c|c|c|c|c|c|c|}
\hline \multirow{2}{*}{ قيمة "ر" } & \multicolumn{2}{|c|}{ التطبيق الثاني } & \multicolumn{2}{|c|}{ التطبيق الاول } & \multirow{2}{*}{ القياس } & \multirow{2}{*}{\multicolumn{2}{|c|}{ الاختبارات }} \\
\hline & $\varepsilon$ & س & $\varepsilon$ & س & & & \\
\hline$* 0.80$ & 0.11 & 4.65 & 0.10 & 4.62 & سم & ذراعين & \multirow{2}{*}{ القوة الانفجارية } \\
\hline$* 0.90$ & 0.06 & 2.22 & 0.07 & 2.20 & سم & رجلين & \\
\hline$* 0.96$ & 0.11 & 1.61 & 0.10 & 1.62 & ث & ذراع يمين & \multirow{4}{*}{ سرعة رد الفعل } \\
\hline$* 0.75$ & 0.09 & 1.72 & 0.08 & 1.74 & ث & ذراع يسار & \\
\hline *0.90 & 0.18 & 2.40 & 0.20 & 2.44 & ث & رجل يمين & \\
\hline *0.97 & 0.17 & 2.61 & 0.19 & 2.63 & $\dot{H}$ & رجل يسار & \\
\hline *0.95 & 0.23 & 24.59 & 0.23 & 24.65 & ث & & رشاقة \\
\hline "*0.76 & 0.42 & 3.80 & 0.48 & 3.70 & ك & ذراع يمين & \multirow{4}{*}{ الدقة } \\
\hline *0.83 & 0.70 & 3.40 & 0.42 & 3.20 & ك5 & ذراع يسار & \\
\hline$* 0.89$ & 0.67 & 3.70 & 0.52 & 3.60 & ك & رجل يمين & \\
\hline *0.87 & 0.63 & 2.80 & 0.48 & 2.70 & ك & رجل يسار & \\
\hline *0.80 & 0.48 & 3.70 & 0.41 & 3.60 & ك5 & ذراع يمين & \multirow{4}{*}{ دقة القدرة } \\
\hline *0.76 & 0.48 & 3.30 & 0.32 & 3.20 & ك & ذراع يسار & \\
\hline$* 0.89$ & 0.67 & 3.70 & 0.22 & 3.60 & ك & رجل يمين & \\
\hline *0.67 & 0.42 & 3.20 & 0.12 & 3.10 & ك5 & رجل يسار & \\
\hline
\end{tabular}

ق قيمة (ر) الجدولية عند مستوي 0.05 0.032 يتضح من جدول (9) وجود علاقة ارتباطية دالة احصائياً عند مستوي 0.05 بين نتائج

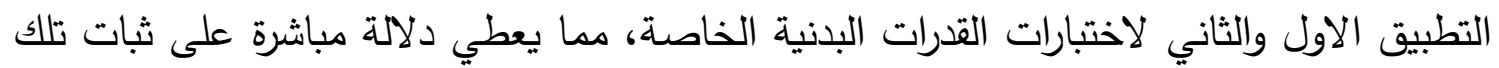
الاختبارات. 
جدول (10)

معامل الثبات للاختبارات في اختبارات القدرات البذنية المهارية(مهارات مركبة) ن= 10

\begin{tabular}{|c|c|c|c|c|c|c|c|}
\hline \multirow{2}{*}{ قيمة "ر" } & \multicolumn{2}{|c|}{ التطبيق الثاني } & \multicolumn{2}{|c|}{ التطبيق الاول } & \multirow{2}{*}{ القياس } & \multirow{2}{*}{\multicolumn{2}{|c|}{ الاختبارات }} \\
\hline & $\varepsilon$ & س - l - l & $\varepsilon$ & س - س & & & \\
\hline$* 0.93$ & 0.79 & 16.80 & 0.48 & 16.90 & ث & كيزامي جياكو جودان & \multirow{4}{*}{ القوة المميزة } \\
\hline$* 0.92$ & 0.67 & 17.70 & 0.39 & 17.80 & ث & كيزامي كواكي مواشي & \\
\hline$* 0.80$ & 0.48 & 7.30 & 0.52 & 7.40 & ث & جياكو اورا مواشي & \\
\hline *0.84 & 0.57 & 7.10 & 0.42 & 7.20 & 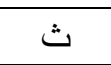 & كيزامي اورا مواشي & \\
\hline *0.94 & 1.25 & 28.00 & 0.62 & 28.20 & ث & كيزامي جياكو جودان & \multirow{4}{*}{ تحمل القدرة } \\
\hline${ }^{*} 0.81$ & 1.06 & 31.30 & 0.47 & 31.50 & ث & كيزامي كواكي مواشي & \\
\hline *0.91 & 0.71 & 15.50 & 0.52 & 15.40 & ث & جياكو اورا مواشي & \\
\hline$* 0.83$ & 0.67 & 15.70 & 0.34 & 15.90 & $\dot{\Delta}$ & كيزامي اورا مواشي & \\
\hline$* 0.75$ & 0.47 & 5.00 & 0.32 & 5.10 & ث & كيزامي جياكو جودان & \multirow{4}{*}{ دقة القدرة } \\
\hline *0.84 & 0.57 & 5.10 & 0.42 & 5.20 & ث & كيزامي كواكي مواشي & \\
\hline$* 0.80$ & 0.70 & 5.40 & 0.22 & 5.60 & ث & جياكو اورا مواشي & \\
\hline${ }^{*} 0.89$ & 0.67 & 5.30 & 0.52 & 5.40 & $ث$ & كيزامي اورا مواشي & \\
\hline
\end{tabular}

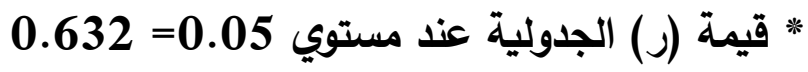
يتضح من جدول (10) وجود علاقة ارتباطية دالة احصائياً عند مستوي 0.05 بين نتائج التطبيق الاول والثاني لاختبارات القدرات البدنية المهارية(مهارات مركبة)، مما يعطي دلالة مباشرة على ثبات تلك الاختبارات.

جلول (11)

معامل الثبات للاختبارات في اختبارات القدرات البذنية المهارية(مهارات فردية) ن= 10

\begin{tabular}{|c|c|c|c|c|c|c|c|}
\hline \multirow{2}{*}{ قيمة "ر" } & \multicolumn{2}{|c|}{ التطبيق الثاني } & \multicolumn{2}{|c|}{ التطبيق الاول } & \multirow{2}{*}{ القياس } & \multirow{2}{*}{\multicolumn{2}{|c|}{ الاختبارات }} \\
\hline & $\varepsilon$ & س - س & $\varepsilon$ & س & & & \\
\hline${ }^{*} 0.88$ & 0.57 & 8.90 & 0.57 & 9.00 & ث & كيزامي جياكو جودان & \multirow{4}{*}{ القوة المميزة } \\
\hline${ }^{*} 0.90$ & 0.67 & 9.00 & 0.44 & 9.10 & ث & كيزامي كواكي مواشي & \\
\hline${ }^{*} 0.82$ & 0.53 & 5.50 & 0.32 & 5.60 & $\dot{H}$ & جياكو اورا مواشي & \\
\hline * 0.80 & 0.52 & 5.60 & 0.48 & 5.70 & ث & كيزامي اورا مواشي & \\
\hline " 0.92 & 0.74 & 14.10 & 0.59 & 14.20 & ث & كيزامي جياكو جودان & \multirow{4}{*}{ تحمل القدرة } \\
\hline${ }^{*} 0.88$ & 0.67 & 12.70 & 0.33 & 12.80 & ث & كيزامي كواكي مواشي & \\
\hline${ }^{*} 0.90$ & 0.63 & 13.80 & 0.64 & 13.90 & ث & جياكو اورا مواشي & \\
\hline$* 0.93$ & 0.82 & 14.00 & 0.68 & 14.10 & ث & كيزامي اورا مواشي & \\
\hline${ }^{*} 0.75$ & 0.47 & 5.00 & 0.32 & 5.10 & ث & كيزامي جياكو جودان & \multirow{4}{*}{ دقة القدرة } \\
\hline${ }^{*} 0.82$ & 0.53 & 5.50 & 0.42 & 5.60 & ث & كيزامي كواكي مواشي & \\
\hline$* 0.76$ & 0.42 & 5.20 & 0.48 & 5.30 & ث & جياكو اورا مواشي & \\
\hline${ }^{*} 0.87$ & 0.48 & 4.70 & 0.33 & 4.80 & $ث$ & كيزامي اورا مواشيي & \\
\hline
\end{tabular}


يتضح من جدول (11) وجود علاقة ارتباطية دالة احصائياً عند مستوي 0.05 بين نتائج التطبيق الاول والثاني لاختبارات القدرات البدنية المهارية(مهارات فردية)، مما يعطي دلالة مباشرة

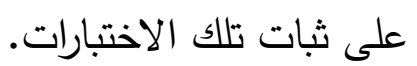
- البرنامج التدريبي المقترح: قام الباحث بإعداد برنامج التدريبات البليومترية بالمقاومة والمساعدة في اتجاه الحركة

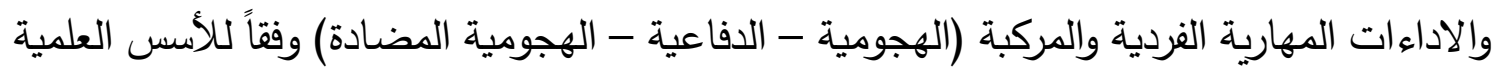
وأيضاً من خلال الاطلاع على المراجع العلمية المتخصصة والدراسات السابقة التالية:

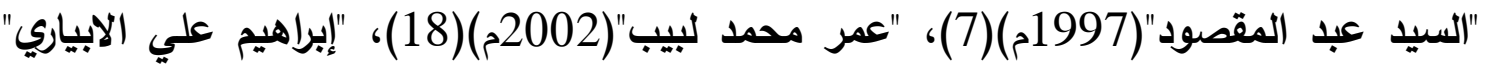

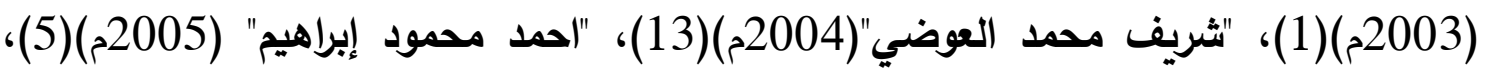

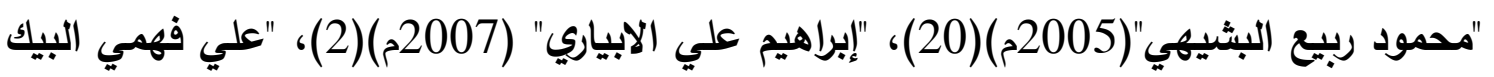

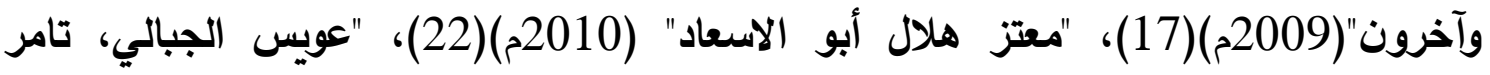

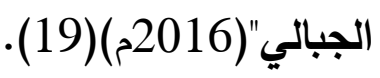

حيث تم تقسيمهم اللى مرحلتين على النحو التالي: (1ل) الأل

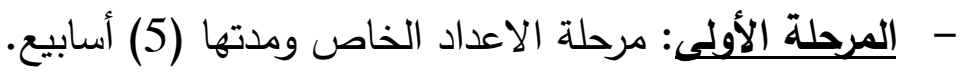
- المرحلة الثانية: مرحلة ما قبل المنافسات ومدتها (4) أسابيح.

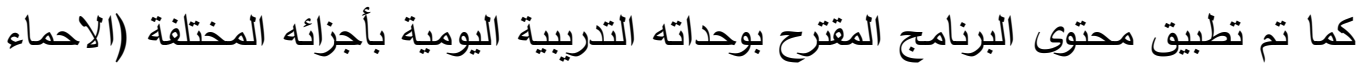

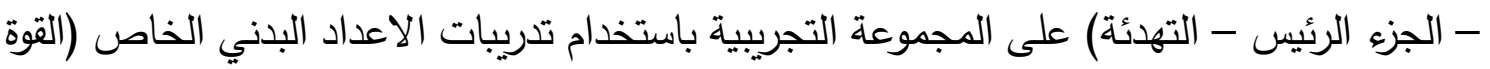

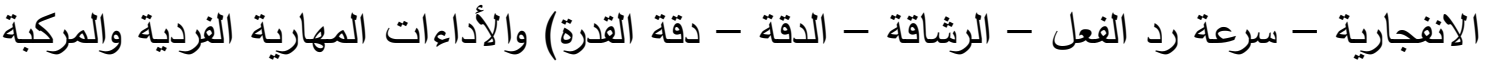

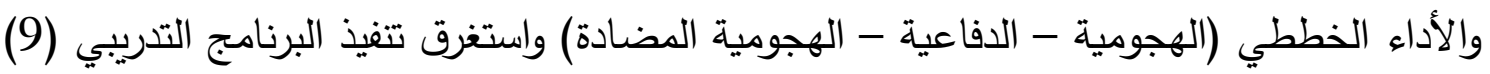
أسابيع بواقع (4) وحدات تدريبية في الأسبوع بإجمالي (36) وحدة تدريبية حيث بلغ زمن الوحدة الوادية

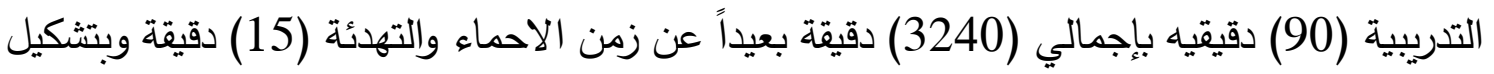
حمل (2:1) أي أسبوع حمل متوسط يتبعه أسبوعين حمل مرتفع. كما تم تحديد زمن الاحماء بواقع (10) دقائق وزمن التهائة (1) دقائق اثناء الوحدة التدريبية

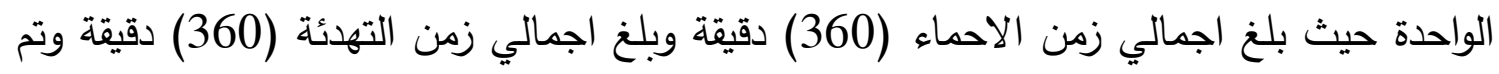

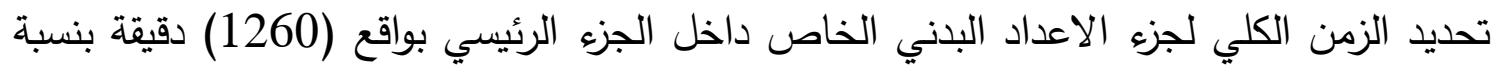
مئوية بلغت 38.8٪ من اجمالي زمن البرنامج بدون الاحماء والتهيئة.

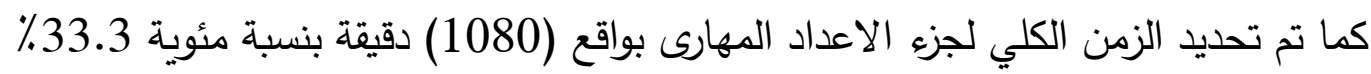
من اجمالي زمن البرنامج بدون الاحماء والتهدئة. كما تم تحديد الزمن الكلي لجزء الاعداد الخططي بواقع (900) دقيقة بنسبة مئوية بلغت 27.8٪ من اجمالي زمن البرنامج بدون الاحماء والتهدئة. 
جدول (12)

برزامج التدريبات البليومترية بالمقاومة والمساعدة في اتجاه الحركة ومستوى الأداء بالنسب والدقائق

\begin{tabular}{|c|c|c|c|c|c|c|c|c|c|c|c|c|}
\hline \multirow{2}{*}{ المئوبية } & \multirow{2}{*}{ المجموع } & \multicolumn{4}{|c|}{ ما قبل المنافسات } & \multicolumn{5}{|c|}{ الاعداد الخاص } & \multirow{2}{*}{\multicolumn{2}{|c|}{ الأسابيع الفترة }} \\
\hline & & التاسع & الثامن & السابع & السادس & الخامس & الرابع & الثالث & الثاني & الأول & & \\
\hline & & 4321 & 4321 & 4321 & 4321 & 4321 & 4321 & 4321 & 4321 & 4321 & \multicolumn{2}{|c|}{ الوحدات } \\
\hline & & & & & & & & & & & أقصى & \multirow{3}{*}{ مستوى الحمل } \\
\hline & & & & & & & & & & & عالي & \\
\hline & & & & & & & & & & & متوسط & \\
\hline & 360 ق & 40 ق & 40 ق & 40 ق & 40 ق & 40 ق & 40 ق & 40 ق & 40 ق & 40 ق & احماء & الجزء التمهيدي \\
\hline \multirow{2}{*}{$\% 38.8$} & \multirow{2}{*}{1260 ق } & 140 ق & 140 ق & 140 ق & 140 ق & 140 ق & 140 ق & 140 ق & 140 ق & 140 ق & الاعداد & \multirow{6}{*}{ الجزء الرئيسي } \\
\hline & & $\% 38.8$ & $\% 38.8$ & $\% 38.8$ & $\% 38.8$ & $\% 38.8$ & $\% 38.8$ & $\% 38.8$ & $\% 38.8$ & $\% 38.8$ & البلني & \\
\hline \multirow{2}{*}{$\% 33.3$} & \multirow{2}{*}{ 1080ق } & 120 ق & 120 ق & 120 ق & 120 ق & 120 ق & 120 ق & 120 ق & 120 ق & 120 ق & الاعداد & \\
\hline & & $\% 33.3$ & $\% 33.3$ & $\% 33.3$ & $\% 33.3$ & $\% 33.3$ & $\% 33.3$ & $\% 33.3$ & $\% 33.3$ & $\% 33.3$ & المهاري & \\
\hline \multirow{3}{*}{$\% 27.8$} & \multirow{2}{*}{900} & 100 ق & 100 ق & 100 ق & 100 ق & 100 ق & 100 ق & 100 ق & 100 ق & 100 ق & الاعداد & \\
\hline & & $\% 27.8$ & $\% 27.8$ & $\% 27.8$ & $\% 27.8$ & $\% 27.8$ & $\% 27.8$ & $\% 27.8$ & $\% 27.8$ & $\% 27.8$ & الخططي & \\
\hline & 360 ق & 40 ق & 40 ق & 40 ق & 40 ق & 40 ق & 40 ق & 40 ق & 40 ق & 40 ق & التهائـة & الجزء الختامي \\
\hline$\% 100$ & 324 ق & 360 ق & 360 ق & 360 ق & 360 ق & 360 ق & 360 ق & 360 ق & 360 ق & 360 ق & \multicolumn{2}{|c|}{ زمن التدريب بدون الاحماء } \\
\hline
\end{tabular}

يوضح جدول (11) برنامج التدريبات البلومترية بالمقاومة والمساعدة في اتجاه الحركة ومستوى الأداء بالنسبة المئوية والدقائق. 
جدول (12)

نموذج للتدريبات المقترحة داخل الوحدة التدرببية اليومية

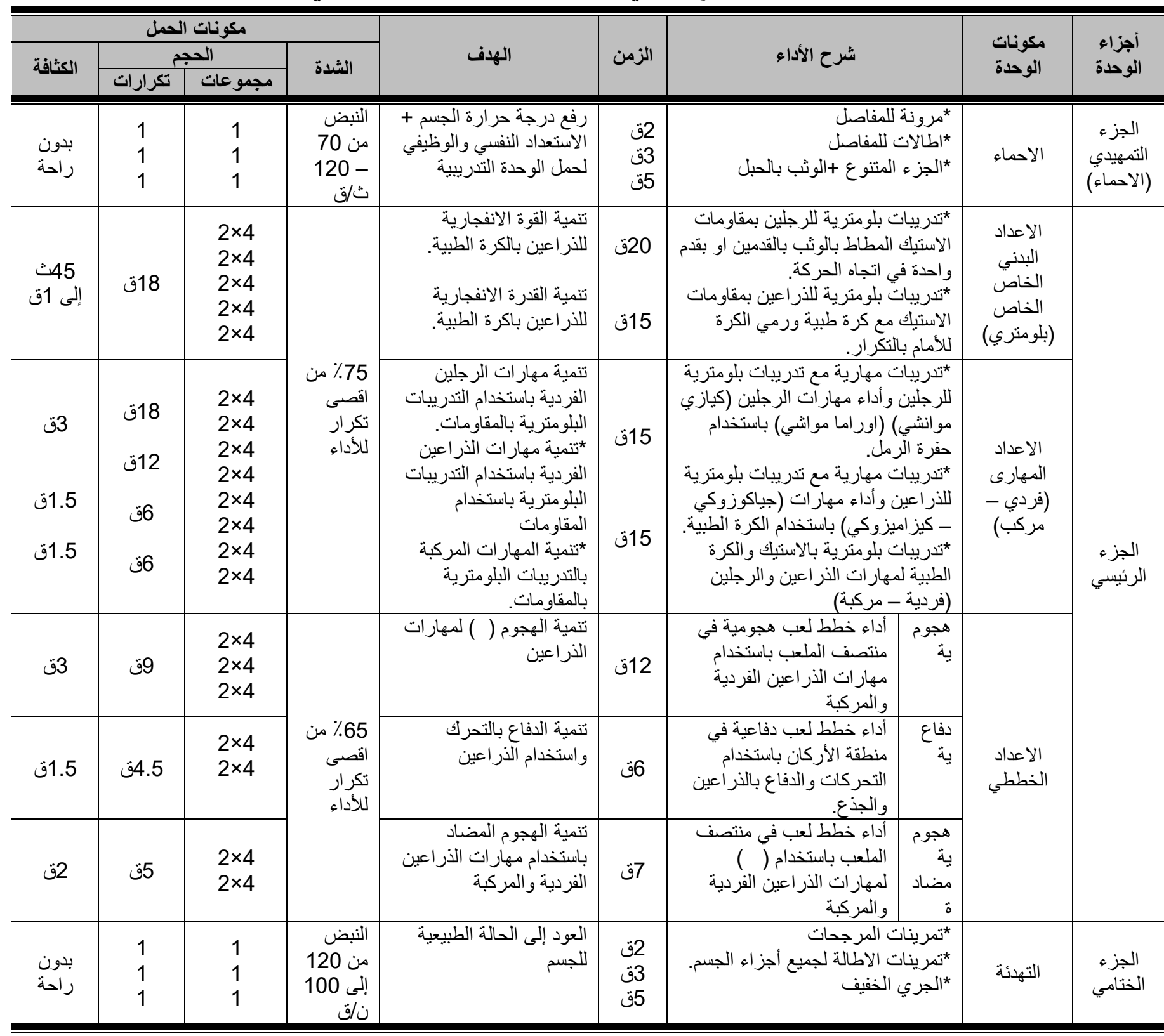

- التجربة الأساسية: - (1) -

$$
\text { 1 - القياس القبلي: }
$$

قام الباحث بإجراء القياس القبلي على عينة الدراسة في المتغيرات قيد الدراسة وذلك يوم الخميس الموافق 24 /1 /2019م وحتى يوم الجمعه الموافق 25 / 1 /2019م بصالة الكاراتيه المعسكر الدائم للمنتخب القومي بالمركز الاوليمبي بالقاهرة.

2- تطبيق البرنامج المقترح:

قام الباحث بتطبيق برنامج التدريبات المقترح على عينة الدراسة وذلك خلال الفترة من يوم السبت الموافق 26 /1 /2019م وحتى يوم الخميس الموافق 28 / 3 /2019م ولمدة (9) أسابيع 
بواقع (4) وحدات أسبوعية باجمالي (36) وحدة تدريبية وذلك بصالة الكاراتيه المعسكر الدائم للمنتخب القومي بالمركز الاوليمبي بالقاهرة.

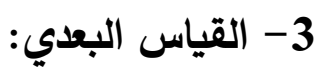
قام الباحث باجراء القياس البعدي على عينة الدراسة في المتغيرات قيد الدراسة وذلك يوم

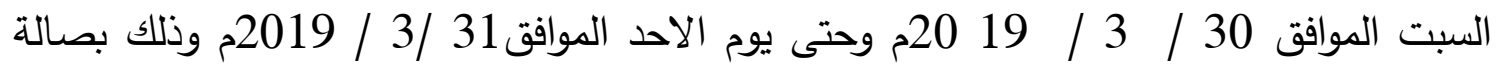
الكاراتيه المعسكر الدائم للمنتخب القومي بالمركز الاوليمبي بالقاهرة. حيث تم تطبيق نفس القياسات التي تم اجرائها في القياس القبلي وتم تفريغ البيانات الخام في استمارة مجهزة لذلك وذلك تمهيداً لإجراء المعالجات الإحصائية. - المعالجات الإحصائية: استخدم الباحث البرنامج الاحصائي للبحوث والعلوم الاجتماعية (SPSS) في المعالجات الإحصائية للبيانات الخام وذلك باستخدام المعالجات الإحصائية التالية:

- المتوسط الحسابي Arithmetic Average. - الانحراف المعياري Standard Deviation - معامل الارتباط "سبيرمان" Sper-man - اختبار (ت) -Equivalent Percentage of Improvement معادلة نسبة التحسن - 


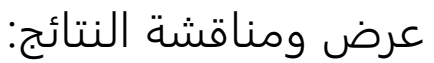

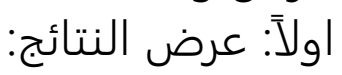

\section{جدول (13)}

دلالة الفروق بين القياسين القبلي والبعدي لأفراد مجموعة (13

البحث في القدات البذنية الخاصة

\begin{tabular}{|c|c|c|c|c|c|c|c|}
\hline \multirow{2}{*}{ قيمة "ت" } & \multicolumn{2}{|c|}{ القياس البعدي } & \multicolumn{2}{|c|}{ القياس القبلي } & \multirow{2}{*}{ القياس } & \multirow{2}{*}{\multicolumn{2}{|c|}{ القدرات البدنية الخاصة }} \\
\hline & $\varepsilon$ & س & $\varepsilon$ & س & & & \\
\hline$* 13.42$ & 0.24 & 5.80 & 0.12 & 4.60 & سم & ذراعين & \multirow{2}{*}{ القوة الانفجارية } \\
\hline$* 29.70$ & 0.07 & 3.18 & 0.07 & 2.20 & سم & رجلين & \\
\hline "*6.10 & 0.14 & 1.27 & 0.10 & 1.62 & $\dot{H}$ & ذراع يمين & \multirow{4}{*}{ سرعة رد الفعل } \\
\hline$* 6.51$ & 0.14 & 1.39 & 0.08 & 1.74 & $ث$ & ذراع يسار & \\
\hline$* 6.93$ & 0.25 & 1.70 & 0.20 & 2.44 & ث & رجل يمين & \\
\hline$* 10.43$ & 0.09 & 1.93 & 0.18 & 2.63 & $\dot{H}$ & رجل يسار & \\
\hline$* 12.84$ & 0.60 & 21.90 & 0.23 & 24.65 & $\dot{H}$ & & الرشاقة \\
\hline *8.05 & 0.52 & 5.60 & 0.48 & 3.70 & ك5 & ذراع يمين & \multirow{4}{*}{ الدقة } \\
\hline$* 8.57$ & 0.47 & 5.00 & 0.42 & 3.20 & ك & ذراع يسار & \\
\hline$* 7.55$ & 0.48 & 5.30 & 0.53 & 3.50 & ك5 & رجل يمين & \\
\hline *8.86 & 0.57 & 4.90 & 0.48 & 2.70 & 5 & رجل يسار & \\
\hline *6.17 & 0.57 & 5.10 & 0.53 & 3.50 & 5 & ذراع يمين & \multirow{4}{*}{ دقة القدرة } \\
\hline$* 7.20$ & 0.57 & 4.90 & 0.42 & 3.20 & ك & ذراع يسار & \\
\hline$* 8.48$ & 0.52 & 5.60 & 0.53 & 3.50 & ك & رجل يمين & \\
\hline$* 10.80$ & 0.42 & 4.80 & 0.32 & 2.90 & 5 & رجل يسار & \\
\hline
\end{tabular}

* قيمة "ت" الجدولية عند مستوي 0.05= 2.262

يتضح من جدول (13) وجود فروق دالة احصائياً عند مستوي 05.050بين القياسين القبلي والبعدي لأفراد مجموعة البحث في القدرات البدنية الخاصة ولصالح القياس البعدي. 
جلول (14)

دلالة الفروق بين القياسين القبلي والبعدي لأفراد مجموعة

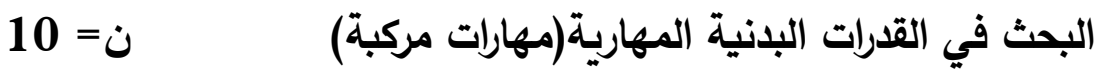

\begin{tabular}{|c|c|c|c|c|c|c|c|}
\hline \multirow{2}{*}{ قيمة "ت" } & \multicolumn{2}{|c|}{ القياس البعدي } & \multicolumn{2}{|c|}{ القياس القبلي } & \multirow{2}{*}{ والقياس } & \multirow{2}{*}{\multicolumn{2}{|c|}{$\begin{array}{c}\text { القدرات البدنية المهارية(مهارات } \\
\text { مركبة) }\end{array}$}} \\
\hline & $\varepsilon$ & س & $\varepsilon$ & س & & & \\
\hline$* 2.30$ & 0.69 & 16.10 & 0.78 & 16.90 & ث & كيزامي جياكو جودان & \multirow{4}{*}{ المالميزة } \\
\hline$* 2.94$ & 0.21 & 17.00 & 0.79 & 17.80 & ث & كيزامي كواكي مواشي & \\
\hline$* 4.00$ & 0.53 & 6.50 & 0.53 & 7.50 & ث & جياكو اورا مواشي & \\
\hline$* 2.26$ & 0.20 & 6.85 & 0.42 & 7.20 & ث & كيزامي اورا مواشي & \\
\hline$* 2.44$ & 0.22 & 27.80 & 0.44 & 28.20 & ث & ي جياكو جودان & \multirow{4}{*}{ القدرة } \\
\hline$* 3.03$ & 0.14 & 31.10 & 0.37 & 31.50 & ث & كيزامي كواكي مواشي & \\
\hline *2.57 & 0.18 & 15.10 & 0.43 & 15.50 & ث & جياكو اورا مواشي & \\
\hline$* 2.56$ & 0.23 & 15.40 & 0.54 & 15.90 & ث & كيزامي اوطا مواشي & \\
\hline *2.74 & 0.30 & 4.70 & 0.32 & 5.10 & ث & كيزامي جياكو جودان & \multirow{4}{*}{ دقة القدرة } \\
\hline$* 2.73$ & 0.26 & 4.75 & 0.42 & 5.20 & ث & إكي مواشي & \\
\hline$* 3.94$ & 0.20 & 5.10 & 0.23 & 5.50 & $ث$ & و اورا مواشي & \\
\hline *3.10 & 0.24 & 4.90 & 0.42 & 5.40 & ث & اورا مواشي & \\
\hline
\end{tabular}

* قيمة "ت" الجدولية عند مستوي 0.05= 262.

يتضح من جدول (14) وجود فروق دالة احصائياً عند مستوي 05 0.05بين القياسين القبلي والبعدي لأفراد مجموعة البحث في القدرات البدنية المهارية(مهارات مركبة)، ولصالح القياس البعدي. 
جدول (15)

دلالة الفروق بين القياسين القبلي والبعدي لأفراد مجموعة (15

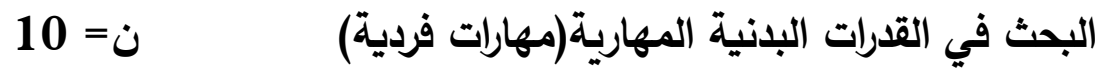

\begin{tabular}{|c|c|c|c|c|c|c|c|}
\hline \multirow{2}{*}{ قيمة "ت" } & \multicolumn{2}{|c|}{ القياس البعدي } & \multicolumn{2}{|c|}{ القياس القبلي } & \multirow{2}{*}{ وحدة } & \multirow{2}{*}{\multicolumn{2}{|c|}{ القدرات البدنية المهارية(مهارات }} \\
\hline & $\varepsilon$ & س س & $\varepsilon$ & س - س & & & \\
\hline$* 2.34$ & 0.28 & 8.70 & 0.43 & 9.10 & ث & كيزامي جياكو جودان & \multirow{4}{*}{ المعيزة } \\
\hline$* 2.69$ & 0.34 & 8.55 & 0.37 & 9.00 & ث & كيزامي كواكي مواثي & \\
\hline$* 3.14$ & 0.21 & 5.10 & 0.32 & 5.50 & ث & جياكو اورا مواشي & \\
\hline$* 3.13$ & 0.10 & 5.15 & 0.32 & 5.50 & ث & كيزامي اورا مواشي & \\
\hline *2.31 & 0.32 & 3.75 & 0.49 & 14.20 & 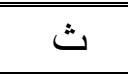 & كيزامي جياكو جودان & \multirow{4}{*}{ القدرة } \\
\hline$* 3.30$ & 0.22 & 12.45 & 0.23 & 12.80 & $ث$ & كيزامي كواكي مواشي & \\
\hline$* 2.32$ & 0.17 & 13.55 & 0.42 & 13.90 & ث & جياكو اورا مواشي & \\
\hline *3.39 & 0.31 & 13.70 & 0.17 & 14.10 & ث & كيزامي اورا مواشي & \\
\hline$* 3.00$ & 0.24 & 4.70 & 0.32 & 5.10 & ث & كيزامي جياكو جودان & \multirow{4}{*}{ القدرة } \\
\hline$* 3.95$ & 0.27 & 5.15 & 0.21 & 5.60 & ث & كيزامي كواكي مواشي & \\
\hline$* 2.73$ & 0.22 & 4.90 & 0.38 & 5.30 & ث & جياكو اورا مواشي & \\
\hline$* 2.35$ & 0.30 & 4.45 & 0.33 & 4.80 & ث & كيزامي اورا مواشي & \\
\hline
\end{tabular}

ق قيمة "ت" الجدولية عند مستوي 0.05= 262.02

يتضح من جدول (15) وجود فروق دالة احصائياً عند مستوي 05.05بين القياسين القبلي والبعدي لأفراد مجموعة البحث في القدرات البدنية المهارية(مهارات فردية)، ولصالح القياس البعدي. 


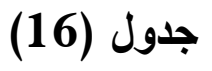

نسب تحسن بين القياس البعدي القياس القبلي لأفراد عينة البحث

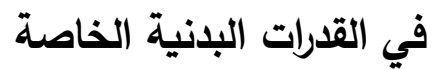

\begin{tabular}{|c|c|c|c|c|}
\hline \multicolumn{3}{|c|}{ افراد مجموعة البحث } & \multirow{2}{*}{\multicolumn{2}{|c|}{ القدرات البدنية الخاصة }} \\
\hline نسب التحسن & بعدي & قبلي & & \\
\hline$\% 26.09$ & 5.80 & 4.60 & ذراعين & \multirow{2}{*}{ القوة الانفجارية } \\
\hline$\% 44.55$ & 3.18 & 2.20 & رجلين & \\
\hline$\% 21.60$ & 1.27 & 1.62 & ذراع يمين & \multirow{4}{*}{ سرعة رد الفعل } \\
\hline$\% 20.11$ & 1.39 & 1.74 & ذراع يسار & \\
\hline$\% 30.33$ & 1.70 & 2.44 & رجل يمين & \\
\hline$\% 26.62$ & 1.93 & 2.63 & رجل يسار & \\
\hline$\% 11.16$ & 21.90 & 24.65 & & الرشاقة \\
\hline$\% 51.35$ & 5.60 & 3.70 & ذراع يمين & \multirow{4}{*}{ الدقة } \\
\hline$\% 56.25$ & 5.00 & 3.20 & ذراع يسار & \\
\hline$\% 51.43$ & 5.30 & 3.50 & رجل يمين & \\
\hline$\% 81.48$ & 4.90 & 2.70 & رجل يسار & \\
\hline$\% 45.71$ & 5.10 & 3.50 & ذراع يمين & \multirow{4}{*}{ دقة القدرة } \\
\hline$\% 53.13$ & 4.90 & 3.20 & ذذراع يسار & \\
\hline$\% 60.00$ & 5.60 & 3.50 & رجل يمين & \\
\hline$\% 65.52$ & 4.80 & 2.90 & رجل يسار & \\
\hline
\end{tabular}

يتضح من جدول (16) وجود نسب تحسن بين القياس القبلي والبعدي لأفراد عينة البحث 
جدول (17)

نسب التحسن بين القياس البعدي القياس القبلي لأفراد عينة البحث

في القدرات البدنية المهارية(مهارات مركبة)

\begin{tabular}{|c|c|c|c|c|}
\hline \multicolumn{3}{|c|}{ افراد مجموعة البحث } & \multirow{2}{*}{\multicolumn{2}{|c|}{ القدرات البدنية المهارية(مهارات مركبة) }} \\
\hline نسب التحسن & بعدي & قبلي & & \\
\hline$\% 4.73$ & 16.10 & 16.90 & كيزامي جياكو جودان & \multirow{4}{*}{ القوة المميزة بالسرعة } \\
\hline$\% 4.49$ & 17.00 & 17.80 & كيزامي كواكي مواشي & \\
\hline$\% 13.33$ & 6.50 & 7.50 & جياكو اورا مواشي & \\
\hline$\% 4.86$ & 6.85 & 7.20 & كيزامي اورا مواشي & \\
\hline$\% 1.42$ & 27.80 & 28.20 & كيزامي جياكو جودان & \multirow{4}{*}{ تحمل القدرة } \\
\hline$\% 1.27$ & 31.10 & 31.50 & كيزامي كواكي مواشي & \\
\hline$\% 2.58$ & 15.10 & 15.50 & جياكو اورا مواشي & \\
\hline$\% 3.14$ & 15.40 & 15.90 & كيزامي اورا مواشثي & \\
\hline$\% 7.84$ & 4.70 & $\overline{5.10}$ & كيزامي جياكو جودان & \multirow{4}{*}{ دقة القدرة } \\
\hline$\% 8.65$ & 4.75 & 5.20 & كيزامي كواكي مواشي & \\
\hline$\% 7.27$ & 5.10 & 5.50 & جياكو اورا مواشي & \\
\hline$\% 9.26$ & 4.90 & 5.40 & كيزامي اورا مواشي & \\
\hline
\end{tabular}

يتضح من جدول (17) وجود نسب تحسن بين القياس القبلي والبعدي لأفراد عينة البحث

في القدرات البدنية المهارية(مهارات مركبة).

جدول (18) 
نسب التحسن بين القياس البعدي القياس القبلي لأفراد عينة البحث

في القدرات البذنية المهارية(مهارات فردية)

\begin{tabular}{|c|c|c|c|c|}
\hline \multicolumn{3}{|c|}{ افراد مجموعة البحث } & \multirow{2}{*}{\multicolumn{2}{|c|}{ القدرات البدنية المهارية(مهارات منفردة) }} \\
\hline نسب التحسن & بعدي & قبلي & & \\
\hline$\% 4.40$ & 8.70 & 9.10 & كيزامي جياكو جودان & \multirow{4}{*}{ القوة المميزة بالسرعة } \\
\hline$\% 5.00$ & 8.55 & 9.00 & كيزامي كواكي مواشي & \\
\hline$\% 7.27$ & 5.10 & 5.50 & جياكو اورا مواشي & \\
\hline$\% 6.36$ & 5.15 & 5.50 & كيزامي اورا مواشي & \\
\hline$\% 3.17$ & 13.75 & 14.20 & كيزامي جياكو جودان & \multirow{4}{*}{ تحمل القدرة } \\
\hline$\% 2.73$ & 12.45 & 12.80 & كيزامي كواكي مواشي & \\
\hline$\% 2.52$ & 13.55 & 13.90 & جياكو اورا مواشي & \\
\hline$\% 2.84$ & 13.70 & 14.10 & كيزامي اورا مواشي & \\
\hline$\% 7.84$ & 4.70 & 5.10 & كيزامي جياكو جودان & \multirow{4}{*}{ دقة القدرة } \\
\hline$\% 8.04$ & 5.15 & 5.60 & كيزامي كواكي مواشي & \\
\hline$\% 7.55$ & 4.90 & 5.30 & جياكو اورا مواشي & \\
\hline$\% 7.29$ & 4.45 & 4.80 & كيزامي اورا مواشي & \\
\hline
\end{tabular}

يتضح من جدول (18) وجود نسب تحسن بين القياس القبلي والبعدي لأفراد عينة البحث

في القدرات البدنية المهارية(مهارات فردية). 
من خلال فروض البحث ومن واقع البيانات والنتائج التي تم التوصل اليها والتي تمت معالجتها احصائيا توصل الباحث الى ما يلي: يتضح من جدول(13) وجود فروق ذات دلالة احصائية عند مستوي معنوية (0.05) بين متوسطي القياسات القبلية والبعدية لأفراد عينة البحث في القدرات البدنية الخاصة (القوة الانفجارية

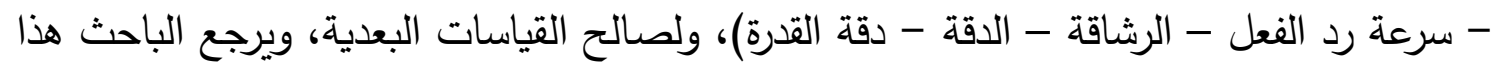

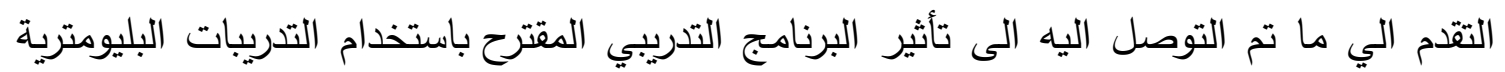

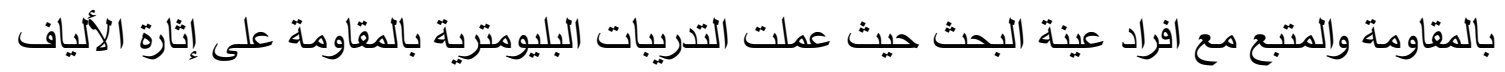

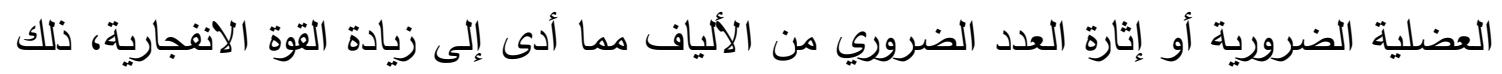

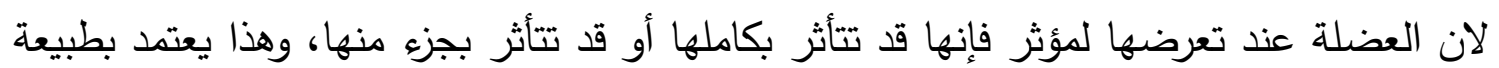

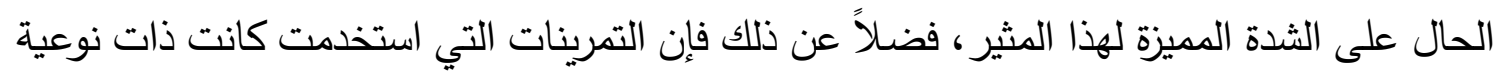
جيدة وموجهة وتصاعدية إلى العضلات العاملة والتي أدت إلى تطور القوة الانفجارية لعضلات

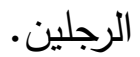

حيث تزيد تدريبات البليومتريك من قدرة عضلات الرجلين على الاداء المتفجر وان المبدأ

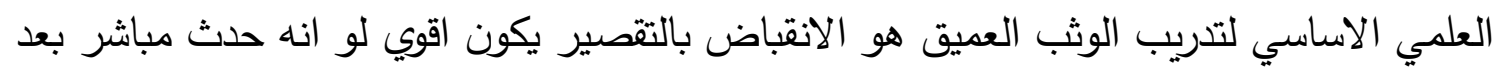

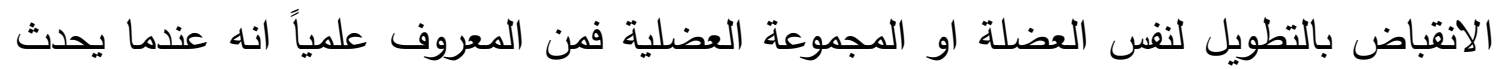

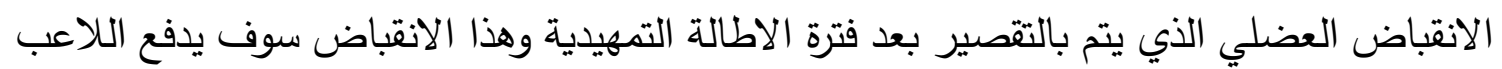

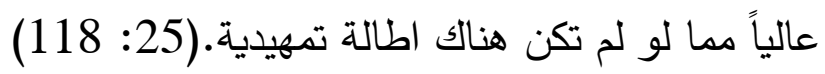
ويؤكد "جورج دون George Dunn" (1999م) ان هناك انواع عديدة من للتدريب البليومتريك تنحصر في الحجلات والوثبات على الحواجز والارتدادات والوثب العميق وذلك بهاف

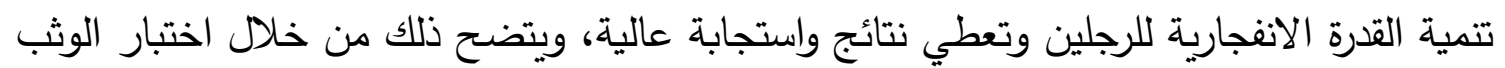
الطويل واختبار العدو.(26: 4681) وهذا يتفق مع نتائج دراسة كلاً من "أيهاب عبد الفتاح وجمال فارس" (261) (2001)) (8)، ودراسة "عارف صالح محسن"(2016)(15)، ودراسة "ثنوف خالد" (2017م)(14)، في أن تدريبات البليومتريك تعمل على زيادة القدرات البدنية الخاصة. مما سبق يتضح تحقيق الفرض الاول للبحث والذي ينص على انه:

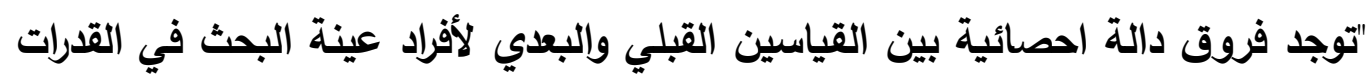
البانية الخاصة بالقدرة العضلية لصالح القياس البعدي".

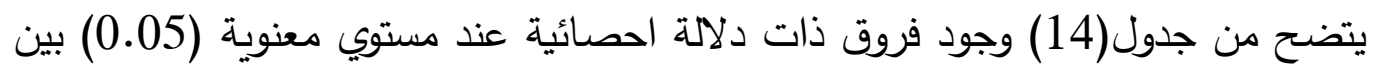

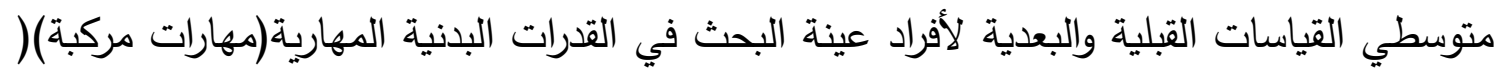

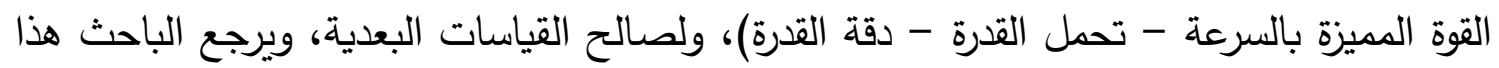


التقدم الي ما تم التوصل اليه الى تأثير البرنامج التدريبي المقترح باستخدام التتريبات البليومترية

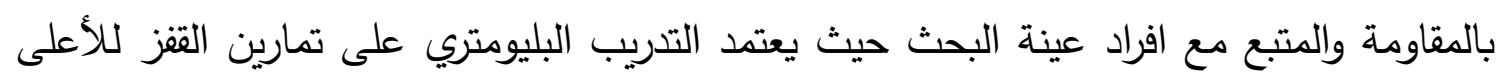

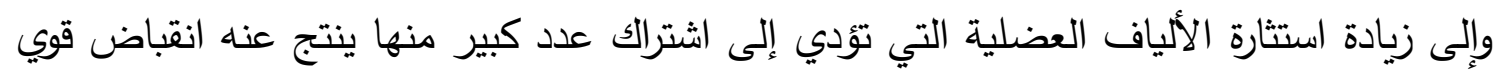

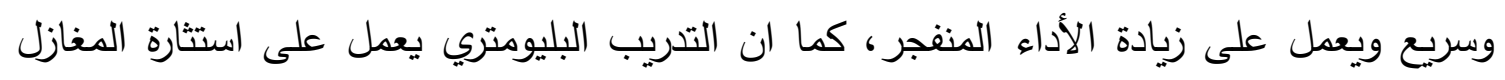

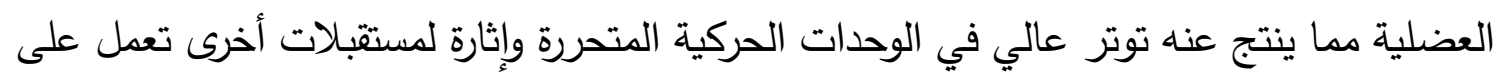
زيادة عدد الألياف العضلية النشطة التي تسبب زيله ليادة القوة الناتجة.

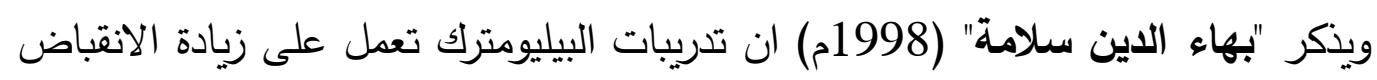

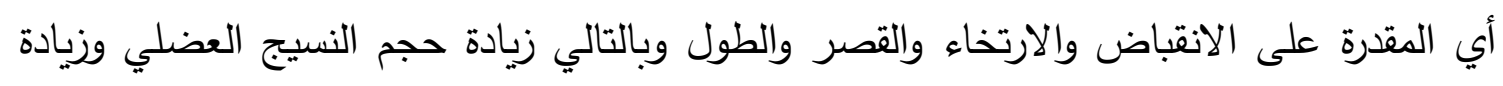

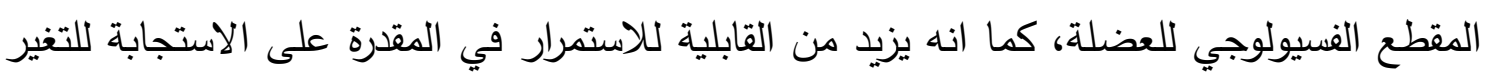
بسرعة.(10: 90)

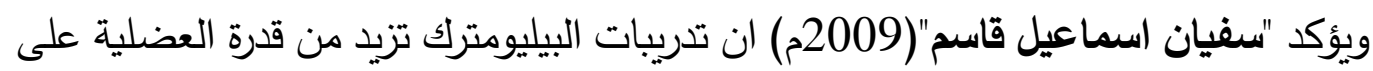
تحمل الزيادة في طولها مثل الانقباض، ويأتي ذلك من خلال زيادة قدرة المغازل العضلية الموجودة

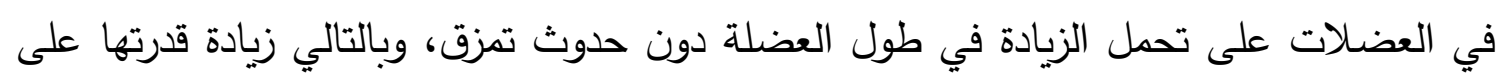

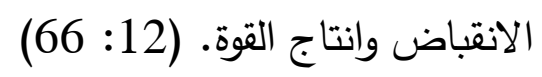
وهذا يتفق مع نتائج دراسة كلاً من "أيهاب عبد الفتاح وجمال فارس" (2001) (2001)(8)، ودراسة "عارف صالح محسن"(2016)(15)، ودراسة "شنوف خالد" (2017م)(14)، في أن تدريبات البليومتريك تعمل على زيادة القدرات البدنية المهارية(مهارات مركبة). مما سبق يتضح تحقيق الفرض الثاني للبحث والذي ينص على اندلى انها:

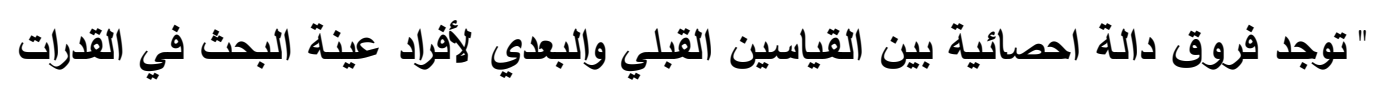
البدنية المهارية (مهارات مركبة) الخاصة بالمستوي المهارى لصالح القياس البعدي".

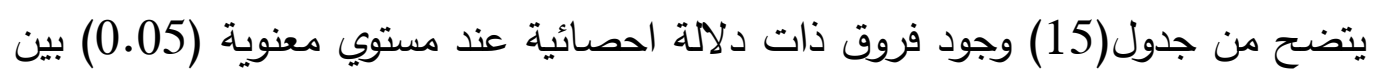

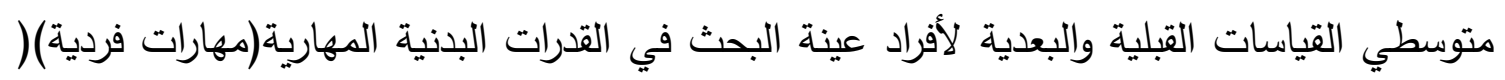

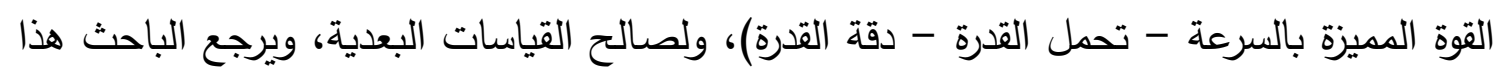

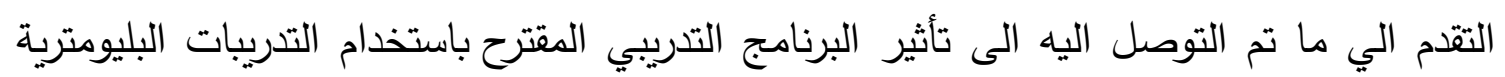

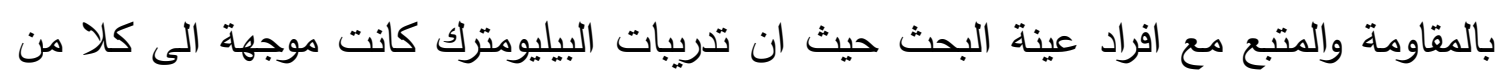
مجموعة الطرف العلوي (الجذع وحزام الكتف والذراعين) وكذلك الطرف السفلي (القدمين والمقعدة)

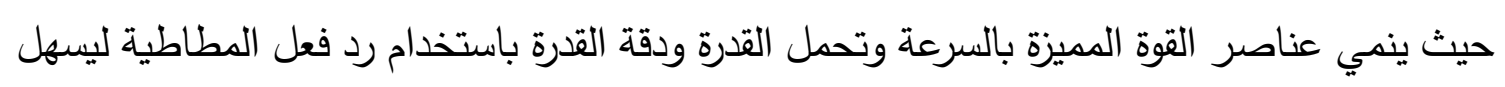
استغلال مجموعة من الوحدات الحركية ويزيد من المطاطية وانقباض العضلات، وبذلك يزيد كفاءة

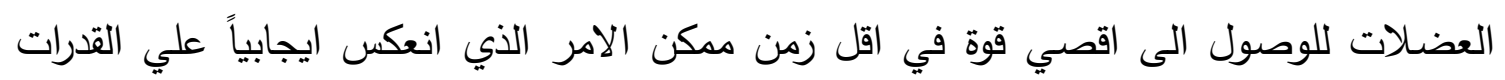
البدنية المهارية(مهارات فردية)( القوة المميزة بالسرعة - تحمل القدرة - دقة القدرة). 
كما يرجع الباحث هذا التقدم الى استخدام تدريبات البيليومترك حيث ان تدريبات البليومترك

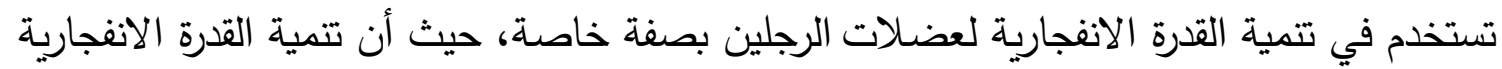

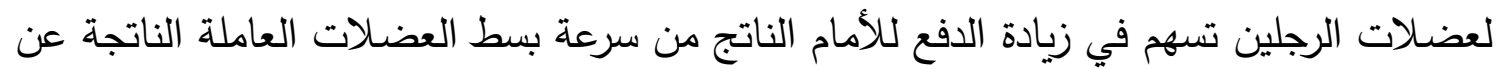

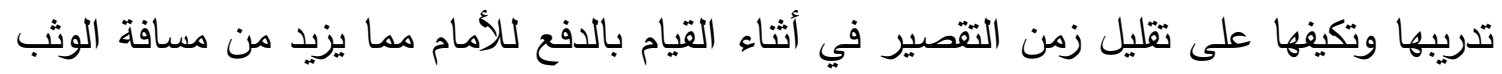

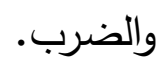

ويتفق ذلك مع "محمود متولي"(2003م) الي ان تدريب الاطالة والتقصير (البليومتريك) يزيد من قدرة العضلات على الانقباض بمعدل اسرع مما يزيد من الاداء الحركي، حيث يتم تدريب

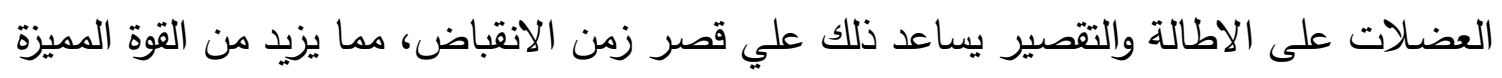
بالسرعة وتحمل القدرة وكذلك دقة القدرة.(21: 291)

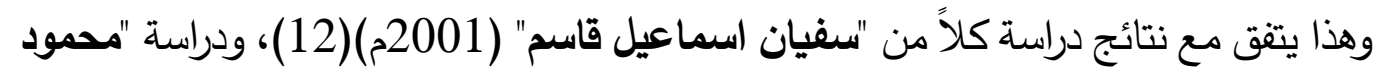
متولي بنداري" (2003م)(21)، ودراسة "حاتم نعمة سمير" (2016م)(11)، في أن تدريبات

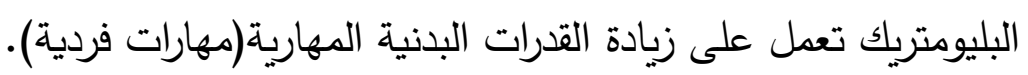
مما سبق يتضح تحقيق الفرض الثالث للبحث والذي ينص على انه:

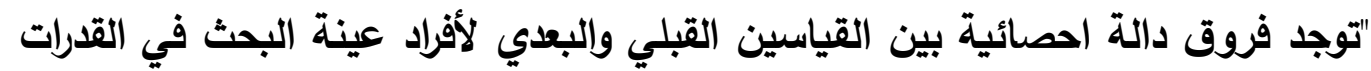
البدنية المهارية (مهارات فردية) الخاصة بالمستوي المهارى لصالح القياس البعدي".

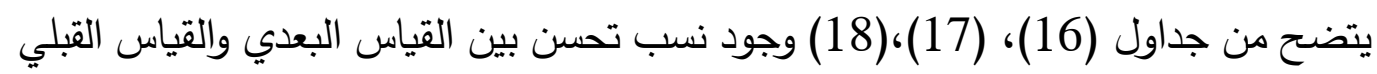
لأفراد عينة البحث في القدرات البدنية الخاصة والقدرات البدنية المهارية (مهارات مركبة) والقدرات البدنية المهارية (مهارات فردية)، حيث تراوحت نسب التحسن بين (11.16٪: 81.48٪) لاختبار

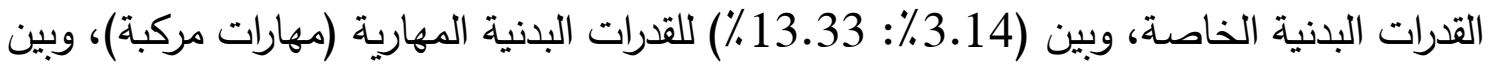

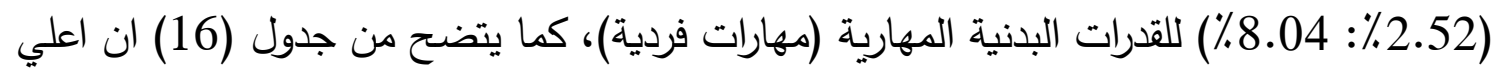

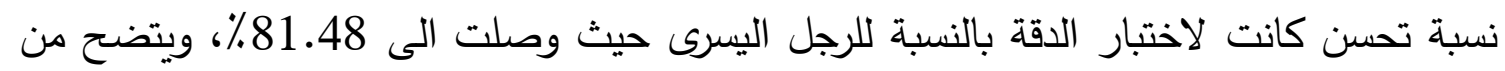

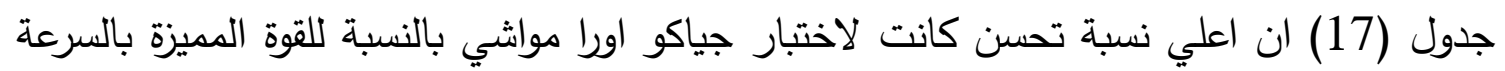
حيث وصلت الى 13.33٪، ويتضح من جدول (18) ان اعلي نسبة تحسن كانت لاختبار كيزامي

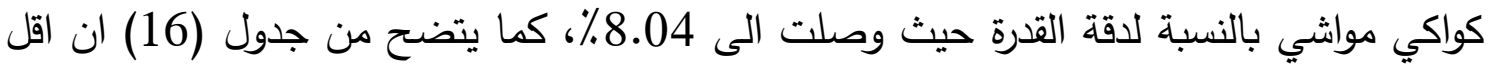
نسبة تحسن كانت للرشاقة بنسبة 11.16٪، ويتضح من جدول (17) ان اقل نسبة تحسن كانت

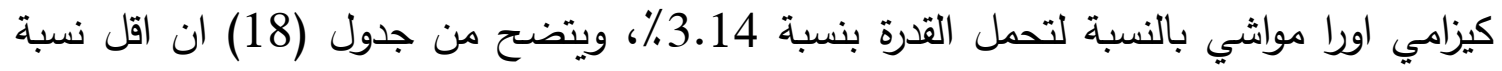

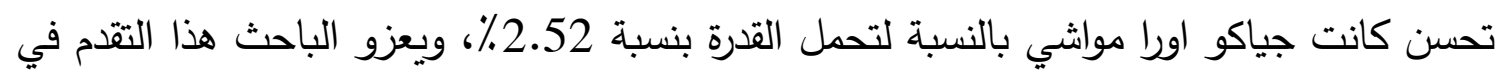

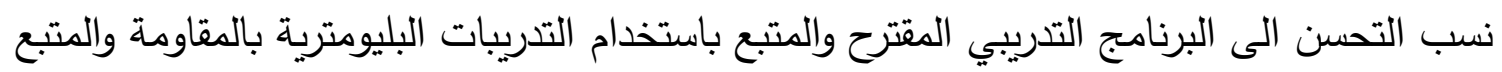

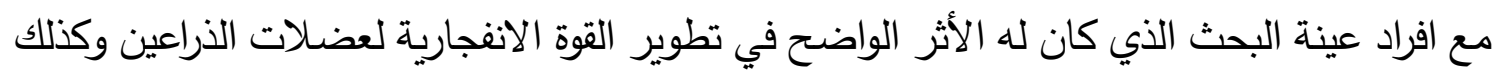

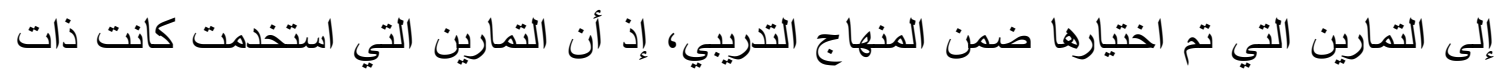




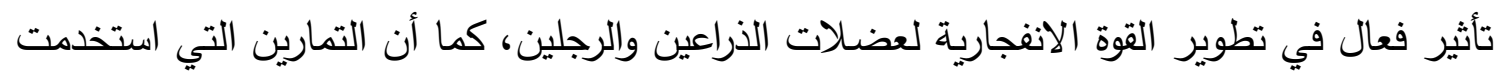
لتطوير القوة الانفجارية لعضلات الذراعين والرجلين أظهرت نتائج جيدة في جميع الاختبار . حيث ان استخدام تدريبات البليومتريك يساعد في تحسين أسلوب استخدام الطاقة المطاطية

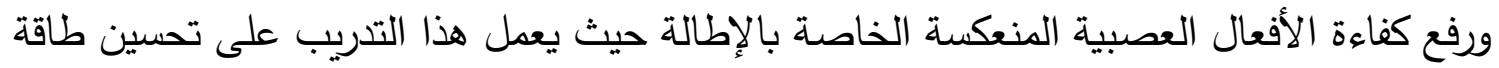
الحركة وطاقة المطاطية التي لهما تأثير كبير على تتمية القدرة العضلية عن طريق دورة الإطالة والتقصير للألياف.(16: 15) وهذا يتفق مع نتائج دراسة كلاً من "أيهاب عبد الفتاح وجمال فارس"(2001) صالح محسن"(2016م)(15)، ودراسة "ثنوف خالد "(2017م)(14)، في دئ أن التدريبات البليومترية بالمقاومة لها تأثير كبير في نسب تحسن كلا من القدرات البدنية الخاصة، والقدرات البدنية المهارية(مهارات مركبة) وكذلك في القدرات البدنية المهارية (مهارات فردية). مما سبق يتضح تحقيق الفرض الرابع للبحث والذي ينص على انه:

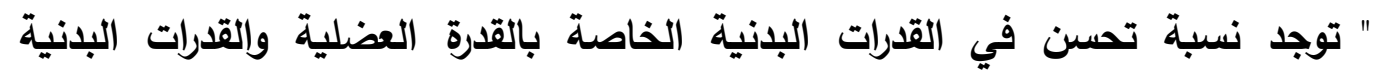

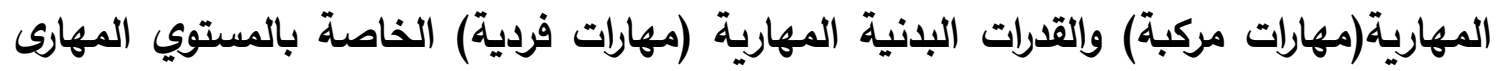
لأفراد عينة البحث (بين القياسين القبلي والبعدي) لصالح القياس البعدي".

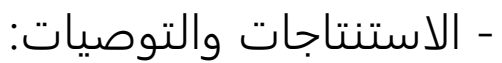

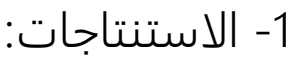

بناء على أهداف البحث وفي حدود العينة وفي ضوء النتائج الاحصائية، توصل الباحث

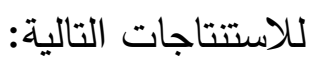

1- يؤثر إستخدام التدريبات البليومترية بالمقاومة على القدرات البدنية الخاصة بالقدرة العضلية

$$
\text { لبلاعبي الكوميتيه. }
$$

r- يؤثر إستخدام التدريبات البليومترية بالمقاومة على القدرات البدنية المهارية (مهارات مركبة)

$$
\text { الخاصة بالمستوي المهارى للاعبي الكوميتيه. }
$$

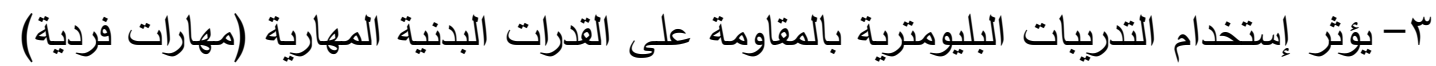
الخاصة بالمستوي المهارى للاعبي الكوميتيه.

ع- توجد نسب تحسن بين القياس القبلي والبعدي في القدرات البدنية الخاصة بالقدرة العضلية

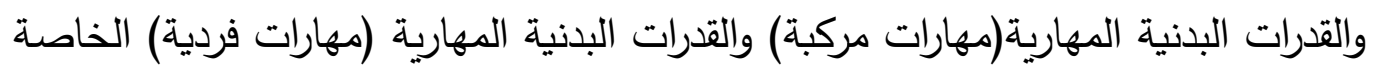

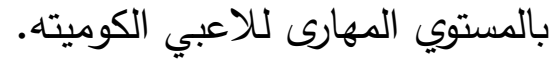

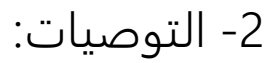
استتاداً الى ما اشارت اليه نتائج البحث يوصي الباحث بالاتي: 
1- تطبيق التدريبات البليومترية بالمقاومة لتتمية القدرات البدنية الخاصة بالقدرة العضلية والقدرات

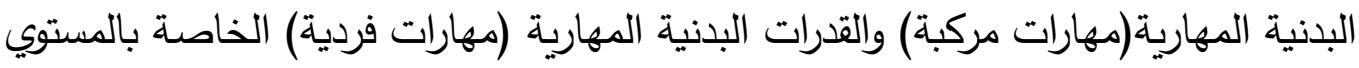

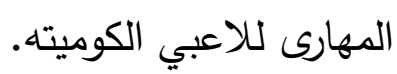
r- اجراء دراسات مشابهة ودراسات مقارنة باستخدام التدريبات البليومترية بالمقاومة بين لاعبي

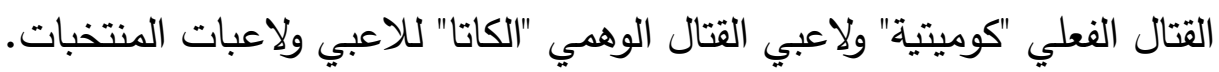

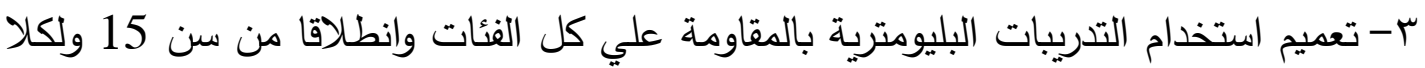

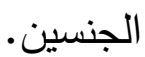
ع - اجراء دراسات اخري باستخدام التدريبات البليومترية بالمقاومة لمختلف التخصصات الأخرى. ه- الاهتمام بالأداء الفني الصحيح عند تطبيق التمرينات لتحقيق أقصى استفادة. 1-توفير واستخدام الأجهزة والأدوات المساعدة عن تطبيق التدريبات البليومترية والأثقال

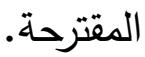

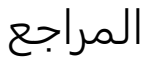


1- ابراهيم على الابيارى (2003م) "تطوير بعض الخطط الهجومية وتأثيره على نتائج المباريات لاى ناشئي رياضة الكاراتيه"، رسالة ماجستير ، كلية التربية الرياضية بالسادات،

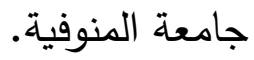

r- ابراهيم على الابياري (2007م): "تصميم منظومة خططية لاخترلق مجال المنافس وتأثيرها على فاعلية الأداء لاى لاعبي رياضة الكاراتيه"، رسالة دكتوراه، كلية التربية الرياضية بالسادات، جامعة المنوفية.

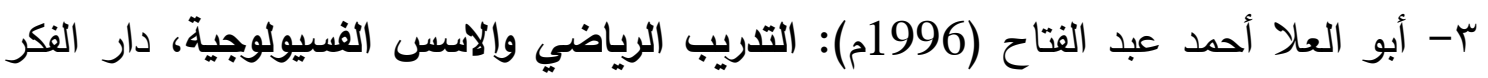

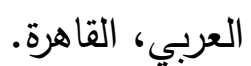

ع - أحمد عبد الرحمن وعز الدين فكري (2004م): منظومة التدريب الرياضي، دار الفكر العربي، القاهرة.

0- أحمد محمود ابراهيم(2005م): موسوعة محددات التدريب الرياضي النظرية والتطبيقية لتخطيط البرامج التدريبية برياضة الكاراتيه، منشاة المعارف، الإسكندرية. ؟- أحمد محمود إبراهيم (1995م): مبادئ التخطيط للبرامج التعليمية والتتريبية للكاراتيه، منشأة الإنيكنة

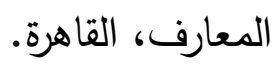
V - السيد عبد المقصود (1997م): نظريات التدريب الرياضي - تدريب وفسيولوجيا القوة، مركز

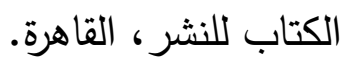

^- أيهاب عبد الفتاح وجمال فارس (2001م): "تأثير استخدام التدريبات البليومترية علي تنمية القدرة العضلية وبعض المتغيرات الفسيولوجية للاعبي التنس"، المجلة العلمية

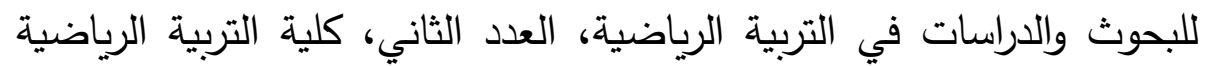

$$
\text { ببورسعيد، جامعة قناة السويس. }
$$

9- بختيار صادق سليم (2015م): تأثير برنامج تدريبي بإستخدام تدريبات البليومتريك على تطوير

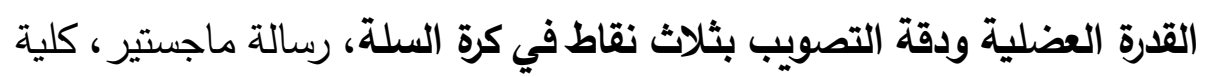
التربية الرياضية للبنين، جامعة الاسكندرية.

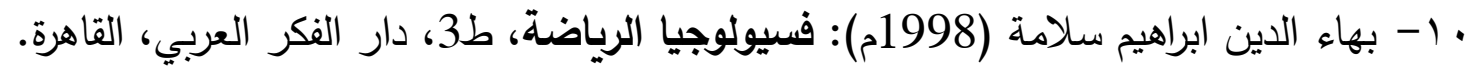
1 ومستوى الانجاز الرقمي للاعبي الوثب الثلاثي بدولة الكويت"، بحث منشور ،

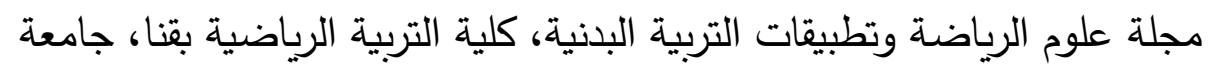

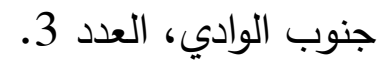


r ا - سفيان اسماعيل قاسم (2009م): "أثر تدريب البليومترك على بعض عناصر اللياقة البذنية وبعض المتغيرات الفسيولوجية لاى لاعبي منتخب كرة الطائرة في جامعة اليرموك"، رسالة ماجستير ، كلية التربية الرياضية، جامعة اليرموك، الاردن.

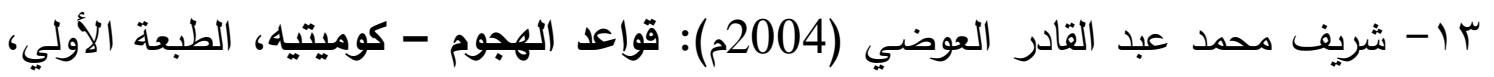
اسلاميك جرافيك، القاهرة.

ع ا- شنوف خالد (2017): "استخدام تدريبات البليومتري والأثقال والمختلط لتطوير القوة الانفجارية وتأثيرها على بعض القدرات البدنية لاى مصارعي الكاراتيه"، رسالة

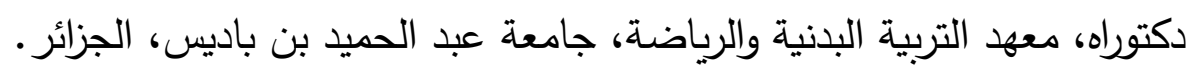

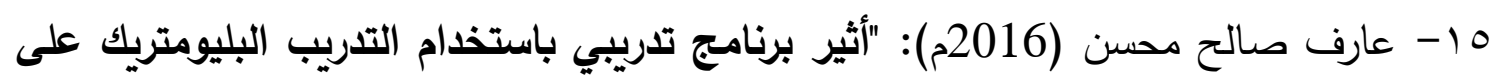

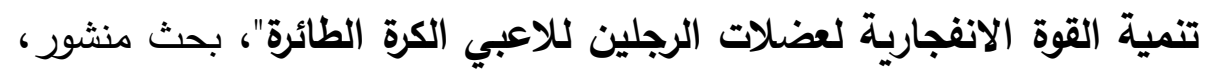

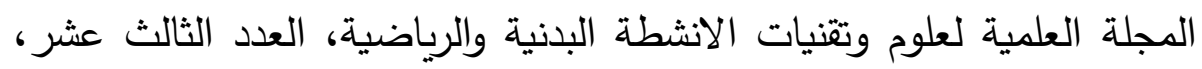

$$
\text { • ديسمبر }
$$

7 ا - عبد الرحمن عبد الحميد زاهر (2001م): موسوعة فسيولوجيا مسابقات الرمي، القاهرة، مركز

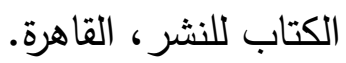

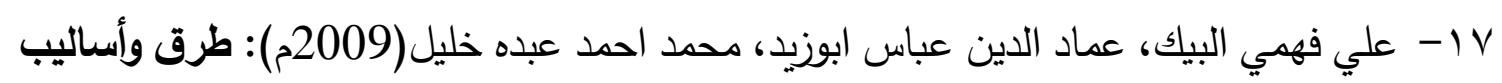

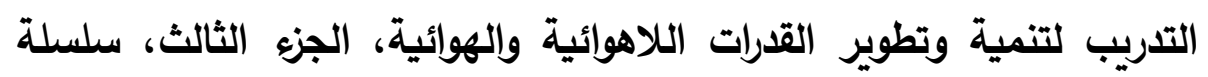

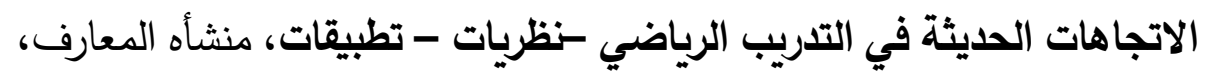

$$
\text { الاسكندرية. }
$$

11- عمر محمد لبيب (2002م): "تأثير برنامج تدريبي مقترح للتوقيت الهجومي على نتائج

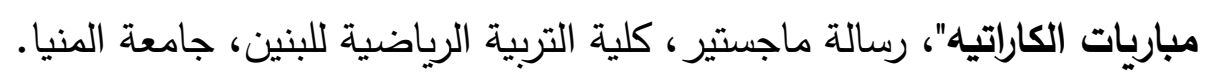

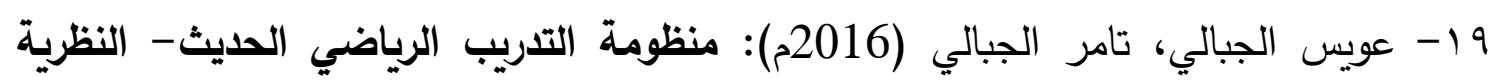
والتطبيق، الطبعة الثالثة، مركز برنت، القاهرة.

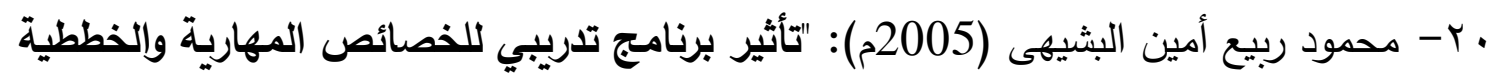
وفق استراتيجية مباريات المستوي العالمي علي مستوي أداء ونتائج لاعبي التئي رياضة الكاراتيه"، رسالة دكتوراه، كلية التربية الرياضية للبنين بالقاهرة، جامعة العيتة حلوان.

ا - - محمود متولي بنداري (2003م): "تأثير برنامج تدريبي بليومتري حس - حركي على تطوير

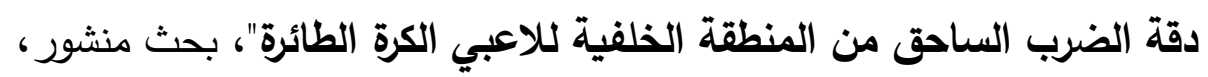
مجلة بحوث التربية الرياضية، المجلد 26، العدد 63، الجزء الثاني، كلية التربية

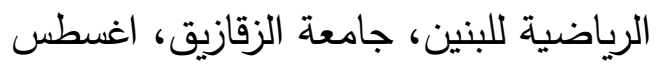


r Y - معتز هلال أبو الأسعاد (2010م): "تأثير برنامج تدريبي على فاعلية أداء بعض المهارات

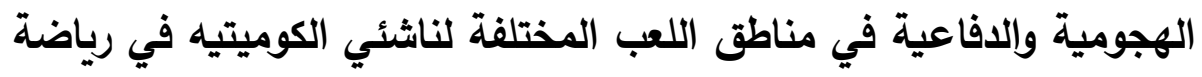

الكاراتيه"، رسالة ماجستير، كلية التربية الرياضية، جامعة المنصورة.

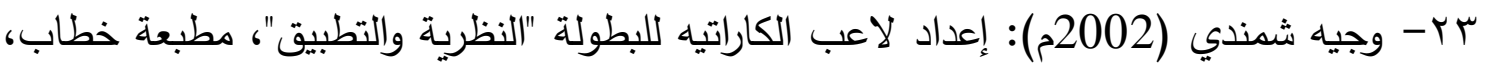

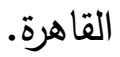

ثانياً: المراجع الاجنبية:

24- Amanda M Turner, \& et al(2003): Improvement training economy after sex weeks of poylomitireic training, The Journal of Strength and Conditioning Research, 17(1):60-7

25- Bennett, JG, and stauber, W.T(1986): Evaluation and treatment of anterior knee pain using eccentric exercise, Med Sci Sports Exerc, oct, 18 (5):526-30.

26- George Dunn(1999): Coach Training to state Championship Track coach formerly track technique, No 147, Spying.

27- Ionic G. Fatuous, D. Ironstone, Kgriakosand, N, Ageless (2000):

Evaluation of polymeric exercise training, weight training and their combination on vertical jumping performance and leg strength. Journal, strength and cond, Res.

28-Marty Dude(1989): Plyometric Legitimate of power training sport medicine, vol . 3 , No 25 march.

29-Stantos, Ej \& Janeira, MA (2011): the effects of resistance training, on explosive strength indicators in adolescent basketball players, Journal of strength and Conditioning Research.

30- William Prentice (1996): Stift stay fit, phd congress cataloging Mosby, U.S.A. 